\title{
6-12 Yaş Arası Zihin Engelli Çocuklarda Görsel Algı Becerilerinin
}

\section{Değerlendirilmesi}

\author{
H.Hakan İNCE ${ }^{1}$, Benan AKDEMİR² Safiye Sunay YILDIRM DOĞRU³
}

${ }^{1}$ Yrd.Doç.Dr.Dicle ÜniversitesiZiya Gökalp Eğitim Fakültesi Okul Öncesi Öğretmenliği ABD. bakanince@dicle.edu.tr

${ }^{2}$ Uzm. Selcuk.ÜniversitesiOkul Öncesi Ögretmenliğ ABD. benanakdemir@,hotmail.com

3 Prof.Dr. Dokuz. Eylül Üniversitesi Buca Eğitim Fakültesi Özel Eğitim Bölümü. sunay.dogru@deu.edu.tr

Bu araștırmada görsel algı becerilerine yönelik geliștirilen araç-gereç ve oyuncakların zihin engelli çocuklarda görsel algı becerilerinin (görsel ayırt etme, görsel eşleştirme, şekil-zemin ayrımı, nesneler arası mekân ilişkisi) gelişimine, yaş, cinsiyet ve özür türü değişkenleri açısından etkisi incelenmiştir. Araştırmaya katılan öğrencilerin, aşamalarda elde ettikleri sonuçlar, görsel algı becerilerini değerlendirme ölçü aracının değerlendirme formuna kaydedilmiş ve değerlendirmesi yapılmıştır.

Araștırmanın sonunda zihin engelli öğrencilerin yașları ile görsel algı becerileri arasındaki ilișki incelendiğinde 9 yaș altı ve 10 yaș üstü olarak kategorilendirilen 6-12 yaş arası zihin engelli öğrencilerin yaşları ile şekil-zemin ilişkisi becerisi, görsel eşleştirme becerisi, görsel ayırt etme becerisi ve nesneler arası mekân ilişkisi becerisi üzerinde anlamlı bir farklılığın olmadığı görülmüştür. Zihin engelli öğrencilerin cinsiyetlere göre görsel alg1 becerileri arasındaki ilișki değerlendirilmiștir. Zihin engelli öğrencilerin cinsiyetleri ile șekil zemin ilișkisi becerisi, görsel eșleștirme becerisi, görsel ayırt etme becerisi ve nesneler arası mekân ilişkisi becerisi üzerinde anlaml bir farklılığın olmadığı görülmüştür.

Zihin engelli öğrencilerin özür türlerine göre görsel alg1 becerileri arasındaki ilişki değerlendirilmiştir. Zihin engelli öğrencilerin özür türleri ile șekil-zemin iliskisi becerisi, görsel ayırt etme becerisi ve nesneler arası mekân iliskisi becerisi üzerinde $\mathrm{p}>0,05$ düzeyinde anlamlı bir farklılık olduğu görülmüştür. Şekil-zemin ilişkisi, görsel eşleştirme, görsel ayırt etme ve nesneler arası mekân ilişkilerine yönelik geliştirilen araç-gereç ve oyuncakları tamamlama sürelerinin görsel alg1 gelişimi üzerindeki etkisi; yaş, cinsiyet ve özür türü değișkenleri açısından incelendiğinde yaș ve cinsiyet değișkenlerinin, araç- gereç ve oyuncakları tamamlama süreleri üzerinde anlaml bir etkisi bulunmamıștır. Özür türü değișkeninde ise șekil-zemin ilișkisi, görsel ayırt etme ve nesneler arası mekân ilișkilerine yönelik geliştirilen araç-gereç ve oyuncakların tamamlanma süreleri arasında anlamlı bir fark bulunmazken, görsel eşleştirme becerisine yönelik geliştirilen araç-gereç ve oyuncağın tamamlanma süresi arasında anlamlı bir fark bulunmuştur.

Anahtar Kelimeler: Görsel alg1, görsel ayırtetme, şekil zemin ilişkisi,nesneler arası mekan ilişkisi

\section{On Visual Apprehension Ability Progressing Of Mentally Defective Children In Between 6-12 Years}

\begin{abstract}
In this search, the affection of instruments and toys which are developed based to visual apprehension ability, on visual apprehension ability progressing of mentally defective children has been examined in the point of age, gender, and defect kind factors. (the visual abilities: visual differentiate, visual coupling, shape - ground connection, the place connection between the material).The results which were obtained from the phases of the participated students, have been recorded to evaluating form of visual apprehensive Ability Evaluating Tool and then evaluated.

At the end of the search, when it was examined the relation between the ages of the defective students and visual apprehension ability; it was seen that there was no meaningful difference between mentally defective students, in between 6 - 12 years; under 9 years, after 10 years categories, and visual differentiate, visual coupling, shape - ground connection, the place connection between the materialsThe relation between the genders of the defective students and visual apprehension ability has been evaluated. It was seen that there was no meaningful difference between the gender of defective students and visual differentiate, visual coupling, shape - ground connection, the place connection between the materials.

The relation between the defect type of the defective students and visual apprehension ability has been evaluated. It was seen that there was a meaningful difference at $\mathrm{p}>0.05$ level between the gender of defective students and visual differentiate, visual coupling, shape - ground connection, the place connection between the materials.It has been found no meaningful relation about the completing duration of the aids and toys which are developed for progressing shape\&place relation, visual matching, visual distinction and place relations among the objects when it was examined on age and gender variables. But, It has been found a meaningful relation about the completing duration of the aids and toys which are developed for progressing shape\&place relation, visual matching, visual distinction and place relations among the objects when it was examined on defect type variable.

Keywords: Mentally defective,visual apprehension visual differentiate, visual coupling, shape - ground connection, the place
\end{abstract} connection between the materials. 


\section{Dicle Üniversitesi Ziya Gökalp Eğitim Fakültesi Dergisi}

\section{GİRIŞ̧}

Yaşam ve öğrenme, görsel uyarıcılarla dolu bir dünyada süregelmektedir. Görsel yetenek temel bir öğrenme kanalı sağlayabilmekte ve sosyal dünya hakkında bilgi edinmenin önemli yollarını oluşturabilmektedir. Getmen, görmeyi zeka ile eşdeğer saymaktadır. "Görme ve zeka çok yakından ilişkilidir. Çocuk neyi görür ve anlarsa, onu bilebilir" (Sayın, 1990; S:24-28).

Görsel alg1 kavramı, görsel uyaranları tanıma, ayırt etme ve daha önceki deneyimlerle ilişkili olarak yorumlama yeteneği anlamına gelmektedir. Görsel algılama yeteneği 3-7 yaşları arasında hız kazanmaktadır. Bu yaşlarda çocuk çevresini, kulakları ve gözleriyle algılayabilir. Nesnelere dokunmaya, tutmaya, tatmaya ya da koklamaya ihtiyacı yoktur. Yine de bu alanda geri kalmış çocuklara rastlanmaktadır. Bu belki çocuklarda farklı hızlardaki olgunlaşma ile açıklanabilir. Görsel bozukluklar sinir sistemi bozukluklarına, beslenmeye veya ağır duygusal bozukluklara da bağlı olabilir. Başarılı bir okuma öğreniminde çocuğun kağıt üzerinde yazılı olan harf ve kelimeleri ayırt edebilmesi için şart olan görsel alg1 becerilerine sahip olması gerekir. Görsel algılama problemleri olan çocuklar öğrenme olayında da geri kalacaklardır. Mekanla konumu algılama yeteneği zayıf olan çocuk, objelerin ve yazılı sembollerin kendisi ile ilişkilerini doğru olarak göremez. Hareketlerinde becerikli ve emin değildir. Mekan-konum ilişkilerini belirten kelimeleri anlamada güçlükler yaşar. Özellikle okuldaki ilk ödevlerinde harfler, kelimeler, cümleler, sayılar ve resimleri bozuk gördüğünden sık hatalar yapması göze çarpar. Örneğin, b harfi d; p harfi ç; ev kelimesi ve; yine 6 rakamı 9; 24 ise 42 olarak algılanır. Bu nedenle okumada, yazmada, hesap yapmada birçok güçlüğü olacaktır (Sağol,1998; S:4).

Öğrenmede özellikle de okuma öğreniminde engelleyici rol oynadığı bildirilen görsel alg1 bozukluklarının erken yaşta saptanması üzerinde önemle durulan konulardan biridir. Genel olarak araştırmacılar, algı ve öğrenme bozukluğu görülen çocukların küçük yaşta teşhis edilmemeleri ve küçük yaşta tedaviye alınmamaları halinde, gelecekte ciddi öğrenme güçlükleri ve buna bağlı bozukluklar geliştirecekleri konusunda görüş birliği içindedirler. Görsel algılama yeteneğinin çocuğun duygusal dengesi üzerinde kuvvetli bir etkisi vardır. Resim yapamayan, kesemeyen, istediğini yazılı olarak anlatamayan bir çocuk kendi becerisini arkadaşlarıyla karşılaştırdığında güvensizlik duygusuna kapılabilir. Çocuk büyüdükçe içinde bulunduğu gerilimden dolayı, enerjisini algılama kusurlarını telafi etmek için kullanacaktır. Ancak zihinsel engelli çocuklar çeşitli nedenlerle bu yetiyi iyi kullanamamaktadırlar (Sağol,1998; S:8).

Çocuğun görsel alg1 yetersizlikleri saptanarak, buna uygun hazırlanmış bir eğitim programı ile çocuğa yardımcı olunabilir. Bu açıdan zihinsel süreçlerin değerlendirilmesi, eğitimi ile ilgili yapılan ve yapılacak olan araştırmalar, geliştirilen testler ve eğitim programları önem kazanmaktadır. Allen, Haupt ve Joes, eğitilebilir zihinsel engelli çocukların görsel algı gelişimleriyle zeka düzeyleri arasındaki ilişkiyi aramışlardır. Uyguladıkları Frostig testi ve WISC zeka testi sonuçlarına göre Frostig testinden yüksek ya da düşük başarı gösteren çocukların WISC testinden de buna paralellik gösteren bir puan elde ettikleri görülmüştür. Bu çalşma zihinsel fonksiyonların ölçümleri üzerinde algısal yetkinliğin katkısını vurgulamıştır. Allen, tekrar buna benzer bir araştırma yapmış ve normal çocuklarla, eğitilebilir zihinsel özürlü çocuklar arasında farklılıklar saptamıştır. Allen'in 1968'de yaptı̆̆ araştırmanın sonuçlan ile 1965'teki araştırmanın sonuçları arasında benzerlikler bulunmaktadır. Morgan, epileptik çocukların görsel alg1 gelişimlerini ölçmek amacıyla yaptı̆̆ çalışmada, çocukların WISC testi ile Frostig testi sonuçlarının yakın ilişki içinde olduğunu saptamıştır (Sağol,1998; S:6).

Bu çalışmanın;

1. Özel eğitimin zihin engelliler grubuyla ilgilenen uzmanlara ve zihin engelli çocuğa sahip olan ailelere, özel eğitimle ilgili ders veren eğitimcilere, özel eğitim alanında program geliştiren uzmanlara yol göstereceği, ülkemizde görsel alg1 becerilerini değerlendirme ölçü aracı ilk kez araştırmacı tarafindan geliştirilip 6-12 yaş arası zihin engelli çocuklara ilk kez uygulandığı için, araştırmanın bu alandaki literatüre katkıda bulunacağı ve Görsel alg1 becerilerini değerlendirme ölçü aracının ilgilenenler tarafından kullanılması için teşvik edici olacağı umulmaktadır. 
Bu çalışmada, zihinsel engelli çocukların görsel alg1 becerilerini (şekil-zemin ilişkisi, görsel eşleştirme, görsel ayırt etme, nesneler arası mekân ilişkisi) tanıma durumları çeşitli değişkenler açısından değerlendirilmiştir. Bu genel amaç doğrultusunda aşağıdaki alt amaçlar geliştirilmiştir:

1.Takvim yaşlarına göre, zihinsel engelli çocuklarda görsel algı becerilerini tanıma durumları (şekil-zemin ilişkisi, görsel eşleştirme, görsel ayırt etme, nesneler arası mekân ilişkisi) farklılaşmakta mıdır ?

2. Cinsiyete göre, zihinsel engelli çocuklarda görsel algı becerilerini tanıma durumları (şekil-zemin ilişkisi, görsel eşleştirme, görsel ayırt etme, nesneler arası mekân ilişkisi) farklılaşmakta mıdır ?

3. Özür türlerine göre, zihinsel engelli çocuklarda görsel algı becerilerini tanıma durumları (şekil-zemin ilişkisi, görsel eşleştirme, görsel ayırt etme, nesneler arası mekân ilişkisi) farklılaşmakta mıdır?

4. Takvim yaşlarına göre zihinsel engelli çocukların görsel algı becerileri ile ilgili olarak hazırlanmış araçgereç ve oyuncakları tamamlama süreleri farklılaşmakta mıdır?

5. Cinsiyete göre zihinsel engelli çocukların görsel algı becerileri ile ilgili olarak hazırlanmış araç-gereç ve oyuncakları tamamlama süreleri farklılaşmakta mıdır?

6. Özür türüne göre zihinsel engelli çocukların görsel alg1 becerileri ile ilgili olarak hazırlanmış araç-gereç ve oyuncakları tamamlama süreleri farklılaşmakta mıdır?

Zihin engelli öğrencilerden görsel alg1 becerilerini değerlendirmeye yönelik elde edilen bilginin doğru ve yeterli olduğu ve zihin engelli çocuklarda görsel algı becerilerini değerlendirmek için kullanılan araç-gereç ve oyuncakların, şekil-zemin ilişkisi, görsel eşleştirme, görsel ayırt etme, nesneler arası mekân ilişkisini ölçmede uygun birer araç olduğu varsayılmıştır.

\section{YÖNTEM}

Bu bölümde, araştırmanın modeli, denekleri, uygulanan deneysel işlem, veri toplama araçları, verilerin çözümlenmesinde kullanılan istatistiksel işlem ve teknikler açıklanmıştır.

\subsection{Araştırmanın Modeli}

$\mathrm{Bu}$ araştırmada görsel alg1 becerilerine yönelik geliştirilen araç-gereç ve oyuncakların, oyuncakları tamamlama sürelerinin zihinsel engelli çocuklarda görsel alg1 becerilerinin (şekil-zemin ilişkisi, görsel eşleştirme, görsel ayırt etme ve nesneler arası mekân ilişkisi) gelişimine, yaş, cinsiyet ve özür türlerine (mental retardasyon, öğrenme güçlüğü, down sendromu, otizm, epilepsi vb.) göre etkililiğinin incelenmesi amacyyla genel tarama modelinin türlerinden ilişkisel tarama modeline göre yapılmıştır. Tarama modelleri, geçmişte ya da halen var olan bir durumu var olduğu şekliyle betimlemeyi amaçlayan araştırma yaklaşımlarıdır. Araştırmaya konu olan olay, birey ya da nesne, kendi koşulları içinde ve olduğu gibi tanımlanmaya çalışılır. Onları herhangi bir şekilde değiştirme, etkileme çabası gösterilmez. (Sarı, 2002; 3).

Genel tarama modelleri, çok sayıda elemandan oluşan bir evrende, evren hakkında genel bir yargı̀a varmak amacı ile evrenin tümü ya da ondan alınacak bir grup, örnek ya da örneklem üzerinde yapılan tarama düzenlemeleridir. Genel tarama modelleri ile tekil ya da ilişkisel taramalar yapılabilir. İlişkisel tarama modelleri iki ve daha çok sayıda değişken arasında birlikte değişim varlığını ve derecesini belirlemeyi amaçlayan araştırma modelidir. Bu tür bir düzenlemede, aralarında ilişki aranacak değişkenler ayrı ayrı sembolleştirilir. Ancak bu sembolleştirme, ilişkisel bir çözümlemeye olanak verecek şekilde yapılmak zorundadır. Değişkenler arasındaki ilişki karşılıklı bağımlılık ya da kısmi bağımlılık şeklinde olabileceği gibi her ikisini de etkileyen üçüncü bir değişkenden kaynaklanabilir (Karasar, 1999; S:77-82).

İlişkisel tarama uygulamasında, araştırmaya katılan deneklere, araştırmacı tarafindan görsel alg1 becerileri temel alınarak; şekil-zemin ilişkisi, görsel eşleştirme, görsel ayırt etme ve nesneler arası mekan ilişsileri boyutlarında hazırlanmış olan araç-gereç ve oyuncaklar kullanılmıştır.

\section{2. Çalışma Grubu}

$\mathrm{Bu}$ araştırmanın çalışma grubunu Milli Eğitim Bakanlığına bağlı, özel ve resmi, Zihin Engelliler ve Rehabilitasyon Merkezlerine devam etmekte olan 6-12 yaş arası toplam 100 zihin engelli çocuk oluşturmaktadır. Çocukların birlikte çalıştığı öğretmenlerle iş birliği yapılarak örneklem belirlenmiş ve örnekleme dahil edilecek çocukların homojen bir grup oluşturabilmesi için ölçüte bağlı örneklem yöntemi ile örneklem seçimi yapılmıştır. Örneklem seçiminde aşağıdaki ölçütler temel alınmıştır; 
Yüz yüze bakabilen, Göz kontağı kurabilen, Sessiz biçimde oturabilen, Öğretmeni izleyebilen,Alıc1 dil düzeyinde verilen yönergeyi anlayabilen (göster !, seç !, al!, yanına koy!, v.b.), Kaba ve küçük kas becerilerini yerine getirebilen, Görsel alg1 becerileri için gerekli olan şekil-zemin ilişkisi, görsel eşleştirme, görsel ayırt etme ve nesneler arası mekân ilişkisi davranışlarını gerçekleştirmeye uygun olan zihin engelli öğrenciler tercih edilmiștir.

\subsection{Veri toplama Arac1 ve Verilerin Toplanmas1}

Araştırma verilerinin toplanmasından önce araştırmanın amaç bölümündeki sorulara cevap verebilecek ön koşul becerilerine sahip olan özel eğitim ve rehabilitasyon merkezlerine devam etmekte olan 100 zihin engelli öğrenci seçilmiştir. Araştırmaya katılan deneklere, araçlar 15 dakikalık oturumlarla ve bireysel olarak uygulanmış, uygulama sonunda görsel algı becerilerine yönelik geliştirilen araç-gereç ve oyuncakların 6-12 yaş arası zihin engelli çocuklarda şekil-zemin ilişkisi, görsel eşleştirme, görsel ayırt etme ve nesneler arası mekân ilişkisi becerilerinin gelişimine yaş, cinsiyet ve özür türlerine göre etkililiği incelenmiştir. İnceleme sonunda iki ve ya daha çok değişken arasında birlikte değişim varlığı ya da derecesi belirlenmiştir.

Araştırmada zihin engelli çocukların görsel algı becerilerini (şekil-zemin ilişkisi, görsel eşleştirme, görsel ayırt etme ve nesneler arası mekân ilişkisi) değerlendirmek için bir araca gereksinim duyulmuş ve zihin engelli çocuklarda kullanılmak üzere "Görsel Alg1 Becerilerini Değerlendirme Ölçü Aracı” geliştirilmiştir. Görsel Alg1 Becerilerini Değerlendirme Ölçü Aracı, görsel algının dört boyutu (şekil-zemin ilişkisi, görsel eşleştirme, görsel ayırt etme ve nesneler arası mekân ilişkisi) nu içeren ve dört aşamadan oluşan araçlardan oluşmaktadır. Ölçü aracında renkler; sarı, kırmızı, mavi ve yeşil ile şekiller; kare, dikdörtgen, üçgen ve daire kullanılmıştır.

Aracın birinci aşamasında, şekil-zemin ilişkisi için; $5 \times 5 \mathrm{~cm}$ ebatlarında yeşil kare, 5x5x5 cm ebatlarında kırmızı üçgen, $6 \times 4 \mathrm{~cm}$ ebatlarında mavi dikdörtgen ve $3 \mathrm{~cm}$ çapında yeşil daire ve her biri dörder adet olan temel şekillerin ahşap düzenek üzerinde kendi yerlerine yerleştirilmesi istenmiştir. Aracın ikinci aşamasında, görsel eşleştirme için; ahşap zemin üzerine yapıştırılmış $5 \times 5 \mathrm{~cm}$ ebatlarında kare, $6 \times 4 \mathrm{~cm}$ ebatlarında dikdörtgen, $5 \times 5 \times 5 \mathrm{~cm}$ ebatlarında üçgen ve $3 \mathrm{~cm}$ çapında daire olmak üzere kırmızı renkli temel şekillerinin yan yana getirilmek suretiyle eşleştirilmesi istenmiştir. Aracın üçüncü aşamasında, görsel ayırt etme için; 5x5 cm ebatlarında 15 adet ahşap kırmızı kare, 6x4 cm ebatlarında 15 adet mavi dikdörtgen, 5x5x5 cm ebatlarında 15 adet sarı üçgen ve $5 \mathrm{~cm}$ çapında 15 adet yeşil daire ile bu temel şekiller ile aynı renkte çuvallar kullanılmıştır. Aynı şekillerin, kendi renklerindeki çuvallara yerleştirilmesi istenmiştir. Aracın dördüncü aşamasında, nesneler arası mekân ilişkisi için; ahşap zemine oyulmuş kanallar arasında hareket edebilen ikişer adet kırmızı, mavi, sarı ve yeşil renklerde toplar kullanılmışır. Topların kanallar arasında hareket ettirilerek kendi renklerindeki yuvalarına yerleştirilmeleri istenmiştir.

Aracın geçerlilik ve güvenirlilik çalışması için, Milli Eğitim Bakanlığına bağlı özel ve resmi özel eğitim kurumları ile rehabilitasyon merkezlerindeki 6-12 yaş arası zihin engelli öğrenciler arasından tesadüfi random yöntemiyle seçilmiş 30 öğrenci üzerinde ön deneme yapilmış ve aracın $\alpha$ güvenirliği $\alpha=.86$ bulunmuştur. Ayrıca araç, Selçuk Üniversitesi Mesleki Eğitim Fakültesi Prof. Dr. İhsan Doğramacı Uygulama Anaokulu'na devam etmekte olan 3-6 yaş aras1 100 öğrenci ile özel eğitim ve rehabilitasyon merkezlerine devam etmekte olan 6-12 yaş arası 100 zihinsel engelli öğrenci olmak üzere toplam 200 öğrenciye uygulanmış ve iki grup görsel algı becerileri (şekil-zemin ilişkisi, görsel eşleştirme, görsel ayırt etme ve nesneler arası mekân ilişkisi) açısından kıyaslanmıştır. Yapılan bağımsız t testi çözümlemesinde iki grup arasında görsel beceriler açısından anlamlı bir fark bulunmuştur. Bu fark aracın geçerliliğinin ve kullanım amacına hizmet ettiğinin bir göstergesi olabileceğini göstermektedir.

Konu ile ilgili olarak yapılan benzer bir çalışmada;

Brand (1989), 68 aylık, Güney Afrikalı 19 beyaz erkek, 12 beyaz kız olmak üzere, toplam 31, özel anaokuluna devam eden çocukla Frostig Gelişimsel Görsel Alg1 Testinin güvenirlik çalışmasını yapmıştır. Frostig Gelişimsel Görsel Alg1 alt alanlarına ait ortalamalar ve standart sapmalar şu şekilde bulunmuştur: GözMotor koordinasyonu (13.94; 9.78), şekil-zemin ayrımı (17.19; 10.21), şekil sabitliği (9.74; 9.56), mekanda konum $(5.87$; 9.92), mekansal ilişkilerin algılanması (4.81;9.95). Frostig alt testlerinin uyum göstergelerini elde etmek için, Kuder-Richardson Formula 20 uygulanmış, alt testler için güvenirlik katsayıları 0.31-0.58 arasında 
değişmiştir. Sabotino, Abbot and Becker (1974), on haftalık sürede yapılan composite Frostig testinde 0.78'lik bir korelasyon bulunmuştur. Testin güvenirlik katsayısı 0.42-0.73 arasında değişmiştir.

Verilerin analizi SPSS istatistik paket programı kullanılarak yapılmıştır. Görsel alg1 becerilerini değerlendirme ölçü aracının güvenirlik çözümlemesinde Cronbach's $\alpha$ testi kullanılmıştır. Aracın geçerlilik çözümlemesi için ise bağımsız t testi kullanılmıştır.

Tablo 1. Normal ve Zihinsel Engelli Çocuklarda Görsel Alg1 Becerilerini Tanıma Durumlarının Karşılaştırılması

\begin{tabular}{|c|c|c|c|c|c|c|c|}
\hline & & $\mathbf{n}$ & & $\mathbf{x}$ & $\mathrm{t}$ & $\mathrm{p}$ & Anlam \\
\hline \multirow{4}{*}{ Şekil Zemin İlişkisi } & Normal & 100 & 1,00 & 0,00 & \multirow{4}{*}{4,180} & \multirow{4}{*}{0,000} & \multirow{4}{*}{$*$} \\
\hline & Zihinsel & & & & & & \\
\hline & Engelli & 100 & 0,85 & 0,36 & & & \\
\hline & Normal & 100 & 0,91 & 0,29 & & & \\
\hline \multirow[t]{3}{*}{ Görsel Eşleştirme } & Zihinsel & & & & \multirow[t]{3}{*}{7,431} & \multirow[t]{3}{*}{0,000} & \multirow[t]{3}{*}{$*$} \\
\hline & Engelli & 100 & 0,48 & 0,50 & & & \\
\hline & Normal & 100 & 0,92 & 0,27 & & & \\
\hline \multirow[t]{2}{*}{ Görsel Ayırt Etme } & Zihinsel & & & & \multirow[t]{2}{*}{4,268} & \multirow[t]{2}{*}{0,000} & \multirow[t]{2}{*}{$*$} \\
\hline & Engelli & 100 & 0,69 & 0,46 & & & \\
\hline \multirow{3}{*}{$\begin{array}{l}\text { Nesneler } \\
\text { İlişkisi }\end{array}$} & Normal & 100 & 0,87 & 0,34 & \multirow{3}{*}{4,212} & \multirow{3}{*}{0,000} & \multirow{3}{*}{$*$} \\
\hline & Zihinsel & & & & & & \\
\hline & Engelli & 100 & 0,62 & 0,49 & & & \\
\hline
\end{tabular}

(*) işareti farkın anlamlı olduğunu göstermektedir. $P<0.05$

Veri toplama amacı ile kurumlara gidildiğinde yöneticilerden uygulamaya alınacak öğrencilerin sınıf kalabalığından etkilenmeyecekleri ve araştırmacı ile bireysel çalışabilecekleri mekânlar istenmiştir. Öğrenciler uygulamaya bireysel alınmışlardır. Zaman zaman sınıf öğretmenleri de uygulamaya katılmışlardır. Veri toplamaya başlamadan önce öğrencilerin rahatlamasını sağlamak amacıyla araştırmada kullanılan araç hakkında kısa bir ön sohbet yapılmıştır. Aracın her bir aşaması öğrencilere tek tek uygulanmış, aşamaları tamamlama süreleri (sn) kaydedilmiş ve sonuçlar görsel beceri değerlendirme formuna işlenmiştir.

Uygulama sürecinde;

Aracin birinci aşamasinda araștırmacl:

“Önünde bulunan şekiller arasından tek tek kare (dikdörtgen, üçgen ve daireyi) 'yi göster”. Yönergesini vermiş ve öğrencinin şekilleri göstermesi beklenmiştir. Öğrenci beş saniye içerisinde istenilenleri göstermişse;

Araştırmacı: “Bu şekilleri masanın üzerinde bulunan düzenek üzerinde, yuvalarına yerleştir.” Yönergesini vermiş ve öğrenciden uygun şekilleri yerlerine yerleştirmesini beklemiştir. Öğrencinin istenilenleri gösterip göstermemesi değerlendirme formuna 1-0 olarak işaretlenmiş ve puanlama yapılmıştır.

Aracm ikinci aşamasında araştırmac:

“Önünde bulunan parçalar içerisinde kare( dikdörtgen, üçgen ve daireyi) 'yi göster”. Yönergesini vermiş ve öğrencinin şekilleri göstermesini beklemiştir. Öğrenci beş saniye içerisinde istenilenleri göstermişse;

Araştırmacı: " Bu şekiller içerisinden aynı olan ikisini yan yana getir" ya da "Bu şekillerin ikizini bul" Yönergesini vermiş ve aynı şekilleri eşleştirmesini beklemiştir. Öğrencinin şekilleri eşleştirip eşleştirmemesi değerlendirme formuna 1-0 olarak işaretlenmiş ve puanlama yapılmıştır.

Aracın üçüncü aşamasinda araştırmacı:

“ Önünde duran şekiller arasından kare( dikdörtgen, üçgen ve daireyi) 'yi göster”. Yönergesini vermiş ve öğrencinin şekilleri göstermesini beklemiştir. Öğrenci beş saniye içerisinde istenilenleri göstermişse;

Araştırmacı: "Bu şekillerden her birini renklerine göre hazırlanmış çuvallara doldur". Yönergesini vermiş ve öğrencinin kendisinden istenileni yapmasını beklemiştir. Öğrencinin aynı şekilleri aynı çuvala doldurup doldurmaması değerlendirme formuna 1-0 olarak işaretlenmiş ve puanlama yapılmıştır.

Aracın dördüncü aşamasında araştırmac:

"Sar1 ( kırmızı, mavi ve yeşil) topu göster”. Yönergesini vermiş, öğrencinin topları istenilen sırayla ve renklerine göre göstermesini beklemiştir. Öğrenci beş saniye içerisinde istenilenleri göstermişse;

"Kanallar içerisinde sarı ( kırmızı, mavi ve yeşil) topu hareket ettirerek ait oldukları yerlere yerleştir". Yönergesini vermiş ve öğrencinin istenilenleri yapmasını beklemiştir. Öğrencinin topları yerlerine yerleştirip yerleştirmemesi değerlendirme formuna 1-0 olarak işaretlenmiş ve puanlama yapılmıştır. 
Görsel algı becerilerine yönelik geliştirilen aracın aşamalarının, tek seferde, bireysel olarak tamamlandığı uygulama süresi her öğrenci için 5-12 dk. olmuştur.

Araştırmacı uygulama esnasında öğrencilerin tepkilerini işaret yardımı, sözel yardımla desteklemiş ve yanlış cevaplarda doğru davranışları açıklamıştır.

Genel tarama modeli türlerinden araştırmanın uygulamasında kullanılmak üzere Görsel Alg1 Becerilerini Değerlendirme Ölçü Aracının Değerlendirme Formu hazırlanmıştır.

Araştırmda kullanılacak olan form birer sayfadan oluşmakta olup bir tablo halinde hazırlanmıştır. Tablo değerlendirilecek olan görsel becerileri ve bu becerilerle ilgili aşamaları içermektedir. Tablonun üst kısmında cinsiyet, yaş ve kurum adı ile tarihe yer verilmiştir.

Başarıyla tamamlanan aşamalar 1, tamamlanamayan aşamalar ise 0 ile puanlandırılmıştır. Değerlendirme formu her bir öğrenci için bireysel olarak doldurulmuştur.

\subsection{Verilerin Analizi}

Görsel algı becerileri (şekil- zemin ilişkisi, görsel eşleştirme, görsel ayırt etme, nesneler arası mekân ilişkisi) ne yönelik olarak gelitirilen araç-gereç ve oyuncakların 6-12 yaş arası zihin engelli çocuklarda, yaş, cinsiyet ve özür türü değişkenlerine göre etkili olup olmadı̆ğna bakılmıştır.

Araştırmanın uygulama sürecinde elde edilen veriler ise bağımsız $t$ testi ile çözümlenmiştir. Tüm sonuçlar tek yönlü olarak sınanmış ve anlamlılık düzeyi 0.05 olarak kabul edilmiştir.

\section{BULGULAR}

\subsection{Zihinsel Engelli Çocukları Görsel Algı Becerilerini Tanıma Durumlarının Karşılaştırılması}

Bu bölümde araştırma bulguları ve bulgulara dayalı olarak yapılan yorumlar yer almaktadır. 6-12 yaş arası zihinsel engelli çocuklarda görsel algı becerilerinin (şekil-zemin ilişkisi, görsel eşleştirme, görsel ayırt etme ve nesneler arası mekân ilişkisi) gelişimine yaş, cinsiyet ve özür türlerine göre etkililiğin incelenmesi amacıyla 100 zihinsel engelli öğrenciye uygulanan görsel algı becerilerini değerlendirme ölçü aracının yaş, cinsiyet ve özür türü değişkenleri açısından inceleyen ve anlamlı bir farklılık olup olmadığını ortaya koyan bulgulara yer verilmiştir.

\subsection{Cinsiyete Göre Zihinsel Engelli Çocukların Görsel Alg1 Becerilerini Tanıma Durumlarının}

\section{Karşılaştırılması}

Araştırmanın birinci alt probleminde cinsiyetleri farklı olan zihinsel engelli çocukların görsel algı becerileri tanıma durumları değerlendirilmiştir. Çocukların görsel becerileri; şekil-zemin ilişkisi, görsel eşleştirme, görsel ayırt etme ve nesneler arası mekân ilişkisi becerileri olmak üzere incelenmiş ve tablolaştırılarak, yorumlanmiştır.

Tablo 2.de cinsiyetlerine göre öğrencilerin şekil-zemin ilişkisi, görsel eşleştirme, görsel ayırt etme ve nesneler arası mekân ilişkisi tanıma durumlarının değerlendirilmesine ilişkin bağımsız t-testi sonuçları ile Şekil 1'de karşılaştırmalara ilişkin grafik verilmektedir.

Tablo 2. Cinsiyete Göre Zihinsel Engelli Çocukların Şekil-Zemin İlişkisi, Görsel Eşleştirme, Görsel Ayırt Etme ve Nesneler Arası Mekân İlişkisini Tanıma Durumlarının Karşılaştırılması

\begin{tabular}{|c|c|c|c|c|c|c|c|}
\hline & Cinsiyet & n & $\overline{\mathbf{x}}$ & ss & $\mathbf{t}$ & $\mathrm{p}$ & Anlam \\
\hline \multirow{2}{*}{ 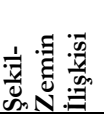 } & $\mathrm{K} 1 \mathrm{z}$ & 41 & 0,90 & 0,30 & \multirow[t]{2}{*}{1,281} & \multirow[t]{2}{*}{0,203} & \multirow{2}{*}{ - } \\
\hline & Erkek & 59 & 0,81 & 0,39 & & & \\
\hline \multirow{2}{*}{ 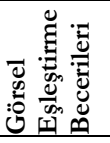 } & $\mathrm{K}_{1 z}$ & 41 & 0,56 & 0,50 & \multirow{2}{*}{1,350} & \multirow{2}{*}{0,18} & \multirow{2}{*}{-} \\
\hline & Erkek & 59 & 0,42 & 0,50 & & & \\
\hline \multirow[b]{2}{*}{ 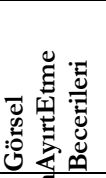 } & $\mathrm{K}_{1 \mathrm{z}}$ & 41 & 0,66 & 0,48 & \multirow[b]{2}{*}{$-0,562$} & \multirow[b]{2}{*}{0,575} & \multirow[b]{2}{*}{-} \\
\hline & Erkek & 59 & 0,71 & 0,46 & & & \\
\hline \multirow{2}{*}{ 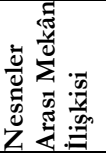 } & $\mathrm{K} 1 \mathrm{z}$ & 41 & 0,61 & 0,49 & \multirow[t]{2}{*}{ _0,174 } & \multirow[t]{2}{*}{0,862} & \multirow[t]{2}{*}{-} \\
\hline & Erkek & 59 & 0,63 & 0,49 & & & \\
\hline
\end{tabular}


Tablo 2. incelendiğinde; kız öğrencilerin şekil-zemin ilişkisi ve görsel eşleştirme becerilerine ilişkin aritmetik ortalamaların, erkek öğrencilere göre daha yüksek olduğu, görsel ayırt etme ve nesneler arası mekân ilişkisi becerilerine ilişkin aritmetik ortalamaların ise daha düşük olduğu gözlenmektedir. Bununla birlikte bu farklılığın anlamlı olup olmadığını belirlemek amacıyla yapılan bağımsız t-testi sonucuna göre, farklı cinsiyetlerdeki zihinsel engelli çocukların şekil-zemin ilişkisi, görsel eşleştirme, görsel ayırt etme ve nesneler arası mekân ilişkisi kurabilme becerileri arasında anlamlı bir fark bulunmamıştır ( $p>0.05)$. Bu durum, cinsiyet değişkeninin zihinsel engelli çocukların şekil-zemin ilişkisi, görsel eşleştirme, görsel ayırt etme ve nesneler arası mekân ilişkisi becerileri açısından görsel algılarını farklılaştırmadığı şeklinde yorumlanabilir.

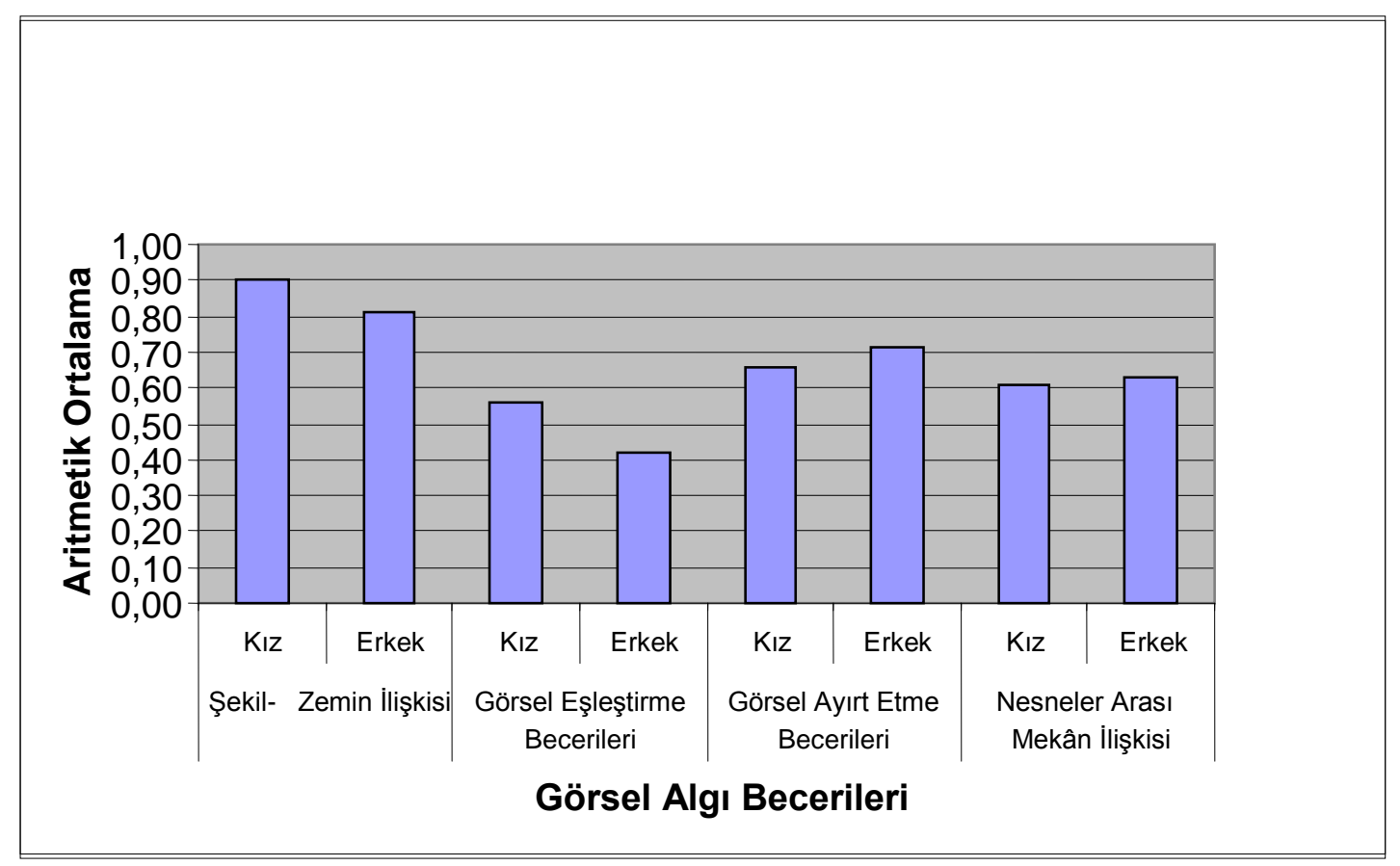

Şekil 1. Cinsiyete Göre Zihinsel Engelli Çocukların Görsel Alg1 Becerilerini Tanıma

Durumlarının Karşılaştırılması

3.3. Takvim Yaşlarına Göre Zihinsel Engelli Çocukların Görsel Algı Becerilerini Tanıma

\section{Durumlarının Karşılaştırılması}

Araştırmanın ikinci alt probleminde takvim yaşları farklı olan zihinsel engelli çocukların görsel algı becerileri tanıma durumları karşılaştırılmıştır. Çocukların görsel becerileri; şekil-zemin ilişkisi becerileri, görsel ayırt etme becerileri, görsel eşleştirme becerileri ile nesneler arası mekan ilişkisi becerileri olmak üzere incelenmiş ve tablolaştırılarak, yorumlanmıştır.

Tablo 3. 'de yaşlarına göre öğrencilerin şekil-zemin ilişkisi becerileri, görsel ayırt etme becerileri, görsel eşleştirme becerileri ve nesneler arası mekan ilişkisini tanıma durumlarının değerlendirilmesine ilişkin bağımsız t-testi sonuçları ile Şekil 2 de karşılaştırmalara ilişkin grafik verilmektedir.

Tablo 3. Takvim Yaşlarına Göre Zihinsel Engelli Çocukların Şekil-Zemin İlişkisi, Görsel Eşleștirme, Görsel Ayırt Etme ve Nesneler Arası Mekân İlişsisini Tanıma Durumlarının Karşılaştırılması

\begin{tabular}{|c|c|c|c|c|c|c|c|}
\hline & Yaş & $\mathrm{n}$ & $\bar{x}$ & ss & $\mathrm{t}$ & $\mathrm{p}$ & Anlam \\
\hline \multirow{2}{*}{ 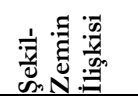 } & & 38 & 0,82 & 0,39 & \multirow{2}{*}{$\__{0,745}$} & \multirow[t]{2}{*}{0,458} & \multirow{2}{*}{-} \\
\hline & $10-12$ & 62 & 0,87 & 0,34 & & & \\
\hline \multirow{2}{*}{ 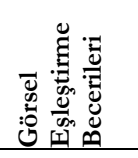 } & $6-9$ & 38 & 0,50 & 0,51 & \multirow{2}{*}{0,310} & \multirow{2}{*}{0,757} & \multirow{2}{*}{-} \\
\hline & $10-12$ & 62 & 0,47 & 0,50 & & & \\
\hline \multirow[b]{2}{*}{ 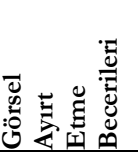 } & $6-9$ & 38 & 0,61 & 0,50 & \multirow[b]{2}{*}{ _1,395 } & \multirow[b]{2}{*}{0,167} & \multirow[b]{2}{*}{-} \\
\hline & $10-12$ & 62 & 0,74 & 0,44 & & & \\
\hline \multirow[b]{2}{*}{ 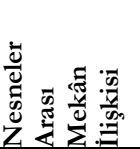 } & $6-9$ & 38 & 0,53 & 0,51 & \multirow[b]{2}{*}{$-^{1,487}$} & \multirow[b]{2}{*}{0,141} & \multirow[b]{2}{*}{-} \\
\hline & $10-12$ & 62 & 0,68 & 0,47 & & & \\
\hline
\end{tabular}

Tablo 3. incelendiğinde, 10-12 yaşları arasındaki öğrencilerin şekil-zemin ilişkisi, görsel ayırt etme becerileri ve nesneler arası mekan ilişkisi becerilerine ilişkin aritmetik ortalamaların, 6-9 yaşları arasındaki 
öğrencilere göre daha yüksek olduğu, görsel eşleştirme becerilerine ilişkin aritmetik ortalamalarının ise daha düşük olduğu gözlenmektedirfarklı yaşlardaki zihinsel engelli çocukların şekil-zemin ilişkisi, görsel eşleştirme, görsel ayırt etme ve nesneler arası mekân ilişkisi becerileri arasında anlamlı bir fark bulunmamıştır ( $\mathrm{p}>0.05)$. Bu durum, yaş değişkeninin zihinsel engelli çocukların şekil-zemin ilişkisi, görsel eşleştirme, görsel ayırt etme ve nesneler arası mekân ilişkisi kurabilme becerileri açısından görsel algılarını farklılaştırmadığı şeklinde yorumlanabilir.

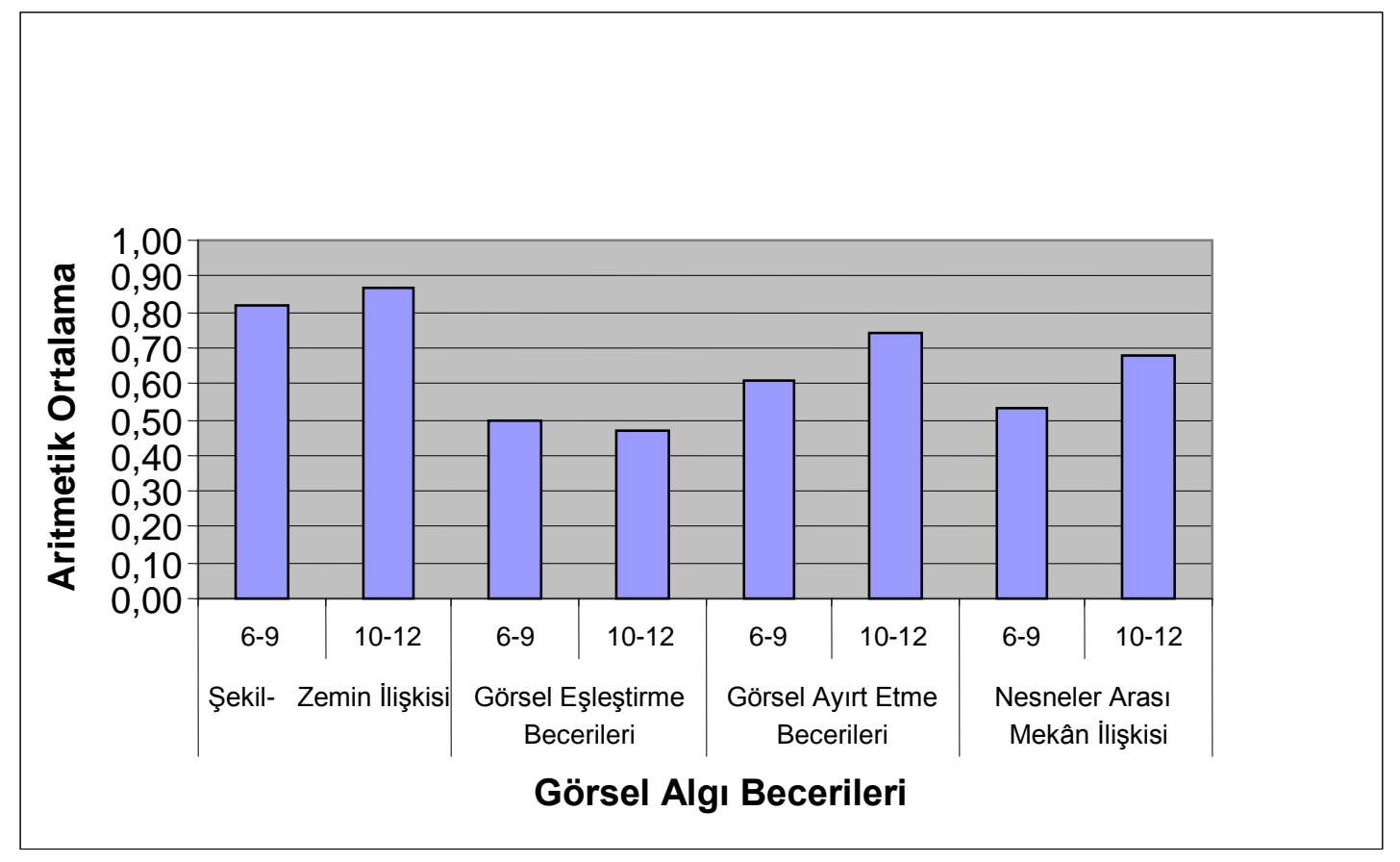

Şekil 2. Takvim Yaşlarına Göre Zihinsel Engelli Çocukların Görsel Alg1 Becerilerini Tanıma Durumlarının Karşılaştırılması

\section{4. Özür Türlerine Göre Zihinsel Engelli Çocukların Görsel Algı Becerilerini Tanıma}

\section{Durumlarının Karşılaştırılması}

Araştırmanın üçüncü alt probleminde özür türleri farklı olan zihinsel engelli çocukların görsel alg1 becerilerini tanıma durumları karşılaştırılmıştır. Çocukların görsel becerileri; şekil-zemin ilişkisi becerileri, görsel ayırt etme becerileri, görsel eşleştirme becerileri ile nesneler arası mekan ilişkisi olmak üzere incelenmiş ve tablolaştırılarak, yorumlanmıştır.

Tablo 4.de özür türlerine göre öğrencilerin şekil-zemin ilişkisi becerileri, görsel ayırt etme becerileri, görsel eşleştirme becerileri ve nesneler arası mekan ilişskisini tanıma durumlarının değerlendirilmesine ilişkin bağımsız t-testi sonuçları ile Şekil 3'de karşılaştırmalara ilişkin grafik verilmektedir. Mental retardasyon özür türü 1, diğer özür türleri (öğrenme güçlüğü, down sendromu, otizm, epilepsi vb.) ise 2 numaraları ile kategorilendirilmiştir.

Tablo 4. Özür Türlerine Göre Zihinsel Engelli Çocukların Şekil-Zemin İlişkisi, Görsel Eşleştirme, Görsel Ayırt Etme ve Nesneler Arası Mekân İlişkisini Tanıma Durumlarının Karşılaştırılması

\begin{tabular}{|c|c|c|c|c|c|c|c|}
\hline & Özür Türü & $\mathrm{n}$ & $x$ & ss & $\mathrm{t}$ & $\mathrm{p}$ & Anlam \\
\hline \multirow{2}{*}{ 富 } & 1 & 59 & 0,95 & 0,22 & \multirow[t]{2}{*}{3,120} & \multirow[t]{2}{*}{0,03} & \multirow[t]{2}{*}{$*$} \\
\hline & 2 & 41 & 0,71 & 0,46 & & & \\
\hline \multirow{2}{*}{ 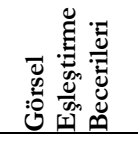 } & 1 & 59 & 0,54 & 0,50 & \multirow{2}{*}{1,500} & \multirow{2}{*}{0,137} & \multirow{2}{*}{ - } \\
\hline & 2 & 41 & 0,39 & 0,49 & & & \\
\hline \multirow{2}{*}{ 总焉焉 } & 1 & 59 & 0,80 & 0,41 & \multirow[t]{2}{*}{2,739} & \multirow[t]{2}{*}{0,008} & \multirow[t]{2}{*}{$*$} \\
\hline & 2 & 41 & 0,54 & 0,50 & & & \\
\hline \multirow[b]{2}{*}{ 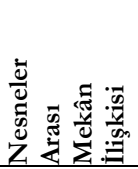 } & 1 & 59 & 0,73 & 0,45 & \multirow[b]{2}{*}{2,705} & \multirow[b]{2}{*}{0,008} & \multirow[b]{2}{*}{$*$} \\
\hline & 2 & 41 & 0,46 & 0,50 & & & \\
\hline
\end{tabular}




\subsubsection{Mental retardasyon}

\subsection{2. Öğrenme Güçlüğü, Down Sendromu, otizm, epilepsi vb.}

Tablo 4.İncelendiğinde, 1 numaralı özür türündeki öğrencilerin şekil-zemin ilişkisi, görsel ayırt etme, görsel eşleştirme ve nesneler arası mekan ilişkisi kurabilme becerilerine ilişkin aritmetik ortalamaların, 2 numaralı özür türündeki öğrencilere göre daha yüksek olduğu gözlenmektedir. Bununla birlikte bu farklıllğın anlamlı olup olmadığını belirlemek amacıyla yapılan bağımsız t-testi sonucuna göre, farklı özür türlerindeki zihin engelli çocukların şekil-zemin ilişkisi, görsel ayırt etme ve nesneler arası mekan ilişkisi becerileri arasında anlamlı bir fark bulunmuştur $(\mathrm{p}<0.05)$. Bu durum, özür türü değişkeninin zihinsel engelli çocukların şekilzemin ilişkisi, görsel ayırt etme ve nesneler arası mekan ilişkisi kurabilme becerileri açısından görsel algılarını farklılaştırdığı şeklinde yorumlanabilir. Buna karşılık görsel eşleştirme becerileri incelendiğinde yapılan bağımsız t-testi sonucuna göre, farklı özür türlerindeki zihinsel engelli çocukların görsel eşleştirme becerileri arasında anlamlı bir fak bulunmamıştır ( $\mathrm{p}>0.05)$. Bu durum, özür türlerindeki değişkeninin zihinsel engelli çocukların görsel eşleştirme becerileri açısından görsel algılarını farklılaştırmadığı şeklinde yorumlanabilir.

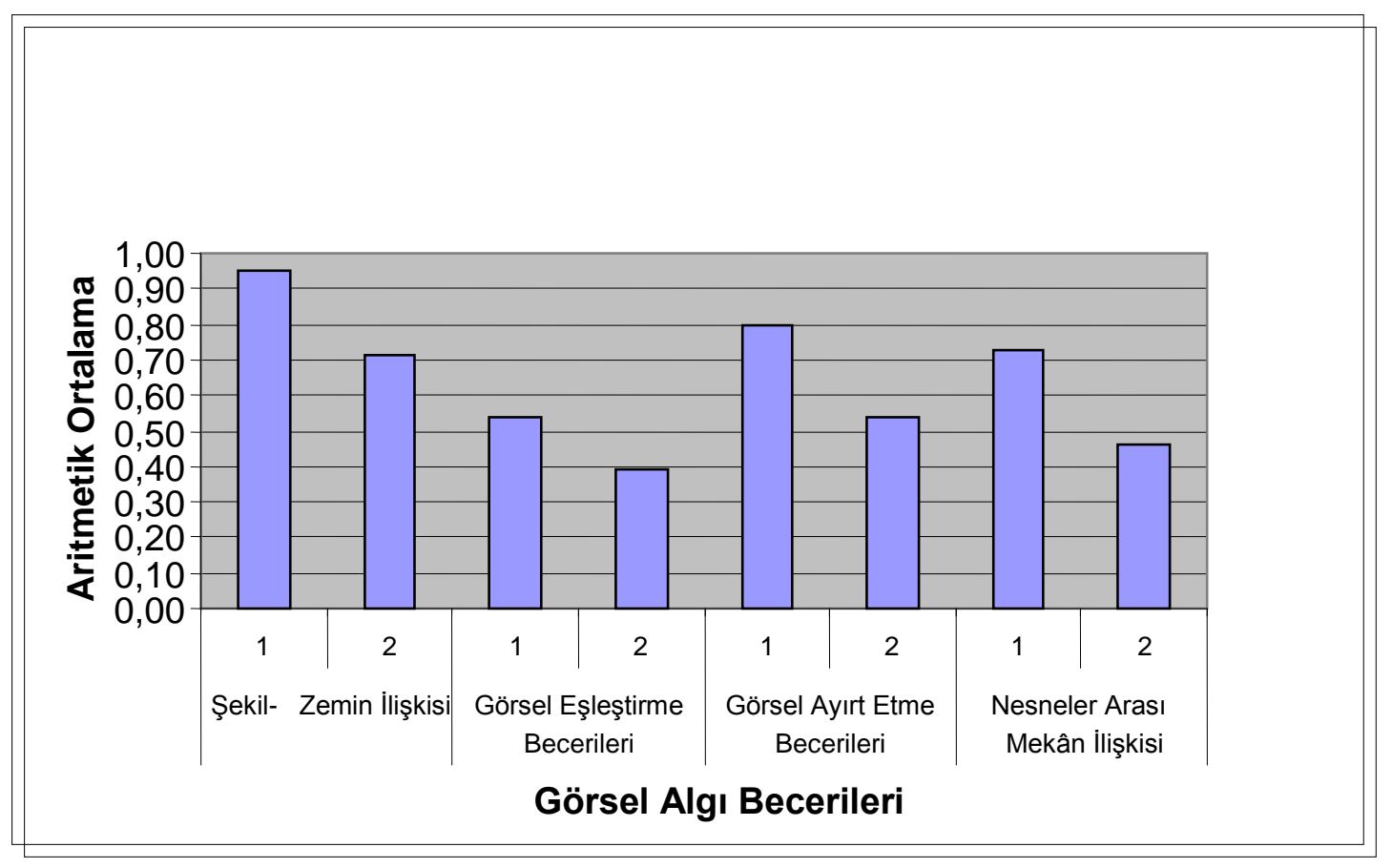

Şekil 3. Özür Türlerine Göre Zihinsel Engelli Çocukların Görsel Alg1 Becerilerini Tanıma Durumlarının Karşılaştırılması

\subsection{Zihinsel Engelli Çocukların Görsel Algı Becerilerini Tanımada Araçları Tamamlama}

\section{Sürelerinin Karşılaştırılması}

Bu bölümde araştırma bulguları ve bulgulara dayalı olarak yapılan yorumlar yer almaktadır. 6-12 yaş arası zihinsel engelli çocuklarda görsel algı becerilerinin (şekil-zemin ilişkisi, görsel eşleştirme, görsel ayırt etme ve nesneler arası mekân ilişkisi) gelişimine yaş, cinsiyet ve özür türlerine göre etkililiğin incelenmesi amacıyla 100 zihinsel engelli öğrenciye uygulanan görsel algı becerileri ile ilgili olarak geliştirilen araç-gereç ve oyuncakları tamamlama sürelerinin, yaş, cinsiyet ve özür türü değişkenleri açısından inceleyen ve anlamlı bir farklılık olup olmadığını ortaya koyan bulgulara yer verilmiştir.

\subsection{Cinsiyete Göre Zihinsel Engelli Çocukların Görsel Alg1 Becerilerini Tanımada Araçları}

\section{Tamamlama Sürelerinin Karşılaştırılması}

Araştırmanın dördüncü alt probleminde, farklı cinsiyetlerdeki, zihinsel engelli öğrencilerin görsel alg1 becerilerini tanıma durumları; şekil-zemin ilişkisi, görsel eşleştirme, görsel ayırt etme ve nesneler arası mekân ilişkisi becerileri alt boyutlarına yönelik olarak geliştirilen araç-gereç ve oyuncakları tamamlama süreleri açısından incelenmiş ve tablolaştırılarak, yorumlanmıştır. Tablo 5. de cinsiyetlerine göre öğrencilerin şekilzemin ilişkisi, görsel eşleştirme, görsel ayırt etme ve nesneler arası mekân ilişkisi becerilerine yönelik olarak geliştirilen araç-gereç ve oyuncakları tamamlarken harcadıkları sürelerin karşılaştırılmasıına ilişkin bağımsız ttesti sonuçları ile Şekil 4 de karşılaştırmalara ilişkin grafik verilmektedir. 
Tablo 5. Cinsiyete Göre Zihinsel Engelli Çocukların Şekil-Zemin İlişkisi, Görsel Eşleştirme, Görsel Ayırt Etme ve Nesneler Arası Mekân İlişkisini Tanımada Araçları Tamamlama Sürelerinin Karşılaştırılması

\begin{tabular}{|c|c|c|c|c|c|c|c|}
\hline & Cinsiyet & $\mathbf{n}$ & $\bar{x}$ & ss & $\mathbf{t}$ & $\mathrm{p}$ & Anlam \\
\hline \multirow[b]{2}{*}{ 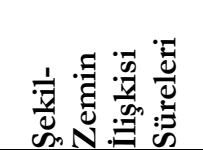 } & $\mathrm{K}_{1 z}$ & 37 & 108,70 & 72,20 & \multirow[b]{2}{*}{ _ 0,457} & \multirow[b]{2}{*}{0,649} & \multirow[b]{2}{*}{-} \\
\hline & Erkek & 48 & 115,42 & 63,04 & & & \\
\hline \multirow{2}{*}{ 焉 } & $\mathrm{K} 1 \mathrm{z}$ & 23 & 80,04 & 39,40 & \multirow{2}{*}{0,689} & \multirow{2}{*}{0,495} & \multirow{2}{*}{-} \\
\hline & Erkek & 25 & 73,56 & 22,93 & & & \\
\hline \multirow{2}{*}{ 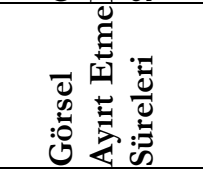 } & $\mathrm{K} 1 \mathrm{z}$ & 27 & 137,70 & 47,99 & \multirow{2}{*}{$\_2,424$} & \multirow{2}{*}{0,18} & \multirow{2}{*}{-} \\
\hline & Erkek & 42 & 166,33 & 47,80 & & & \\
\hline \multirow{2}{*}{ 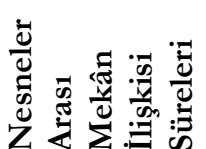 } & $\mathrm{K} 1 \mathrm{z}$ & 25 & 67,44 & 86,13 & \multirow{2}{*}{ _ 0,135} & \multirow{2}{*}{0,893} & \multirow{2}{*}{-} \\
\hline & Erkek & 37 & 69,70 & 45,17 & & & \\
\hline
\end{tabular}

Tablo 5 incelendiğinde; kı öğrencilerin görsel eşleştirme becerisi tamamlama süresine ilişkin aritmetik ortalamaların, erkek öğrencilere göre daha yüksek olduğu, şekil-zemin ilişkisi, görsel ayırt etme ve nesneler arası mekân ilişkisi becerileri tamamlama sürelerine ilişkin aritmetik ortalamaların ise daha düşük olduğu gözlenmektedir. Bununla birlikte bu farklılı̆ın anlamlı olup olmadığını belirlemek amacıyla yapılan bağımsız ttesti sonucuna göre, farklı cinsiyetlerdeki zihin engelli çocukların şekil-zemin ilişkisi, görsel eşleştirme, görsel ayırt etme ve nesneler arası mekân ilişkisi becerilerine yönelik olarak geliştirilen araç-gereç ve oyuncakları tamamlama süreleri arasında anlamlı bir fark bulunmamıştır ( $\mathrm{p}>0.05)$. Bu durum, cinsiyet değişkeninin zihinsel engelli çocukların şekil-zemin ilişkisi, görsel eşleştirme, görsel ayırt etme ve nesneler arası mekân ilişkisi becerileri açısından bu becerilere yönelik geliştirilen araç-gereç ve oyuncakları tamamlama sürelerinin görsel algılarını farklılaştırmadığı şeklinde yorumlanabilir.

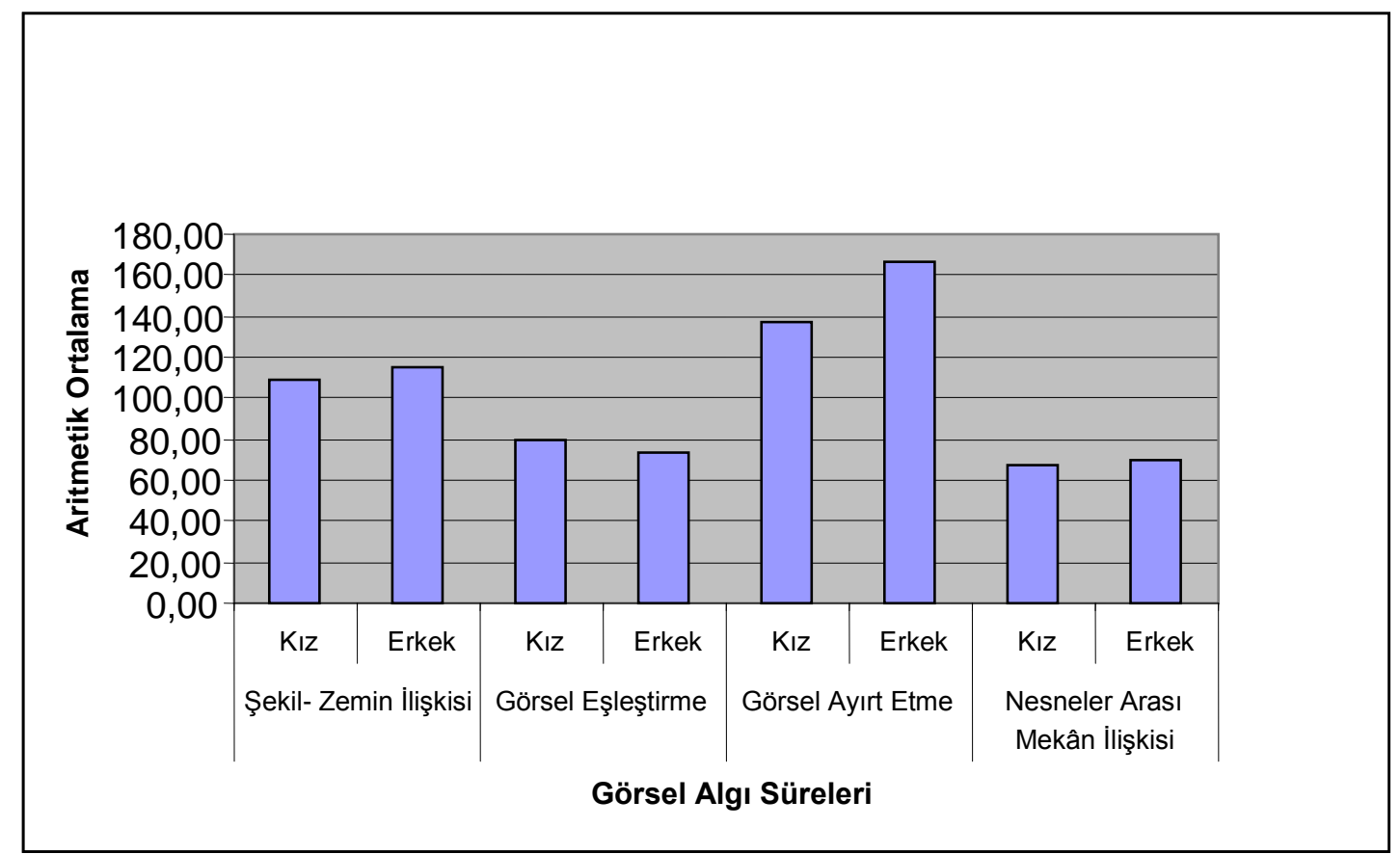

Şekil 4. Cinsiyete Göre Zihinsel Engelli Çocuklarda Görsel Alg1 Becerilerini Tanımada Araçları Tamamlama Sürelerinin Karşılaştırlması

\subsection{Takvim Yaşlarına Göre Zihinsel Engelli Çocukların Görsel Alg1 Becerilerini Tanımada}

\section{Araçları Tamamlama Sürelerinin Karşılaştırılması}

Araştırmanın beşinci alt probleminde, farklı takvim yaşlarındaki, zihinsel engelli öğrencilerin görsel alg1 becerilerini tanıma durumları; şekil-zemin ilişkisi, görsel eşleştirme, görsel ayırt etme ve nesneler arası mekân ilişkisi becerileri alt boyutlarına yönelik olarak geliştirilen araç-gereç ve oyuncakları tamamlama süreleri açısından incelenmiş ve tablolaştırılarak, yorumlanmıştır. 
Tablo 6 da yaşlarına göre öğrencilerin şekil-zemin ilişkisi, görsel eşleştirme, görsel ayırt etme ve nesneler arası mekân ilişkisi becerilerine yönelik olarak geliştirilen araç-gereç ve oyuncakları tamamlarken harcadıkları sürelerin karşılaştırılmasına ilişkin bağımsız t-testi sonuçları ile Şekil 5. de karşılaştırmalara ilişkin grafik verilmektedir.

Tablo 6. Takvim Yaşlara Göre Zihinsel Engelli Çocukların Şekil-Zemin İlişkisi, Görsel Eşleştirme, Görsel Ayırt Etme ve Nesneler Arası Mekân İlişkisini Tanımada Araçları Tamamlama Sürelerinin Karşılaştırılması

\begin{tabular}{|c|c|c|c|c|c|c|c|}
\hline & Yaş & $\mathbf{n}$ & $\overline{\mathbf{x}}$ & ss & $\mathbf{t}$ & $\mathrm{p}$ & Anlam \\
\hline \multirow{2}{*}{ 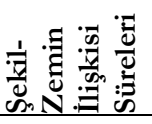 } & $6-9$ & 31 & 111,29 & 54,37 & \multirow{2}{*}{ _0,125 } & \multirow[t]{2}{*}{0,901} & \multirow{2}{*}{-} \\
\hline & $10-12$ & 54 & 113,19 & 73,54 & & & \\
\hline \multirow{2}{*}{ 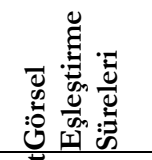 } & 6-9 & 19 & 84,26 & 36,34 & \multirow[b]{2}{*}{1,355} & \multirow[b]{2}{*}{0,182} & \multirow[b]{2}{*}{-} \\
\hline & $10-12$ & 29 & 71,69 & 27,82 & & & \\
\hline 妾 & $6-9$ & 23 & 165,70 & 44,90 & \multirow[b]{2}{*}{1,257} & \multirow[b]{2}{*}{0,213} & \multirow[b]{2}{*}{-} \\
\hline 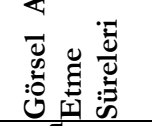 & $10-12$ & 46 & 149,85 & 51,35 & & & \\
\hline 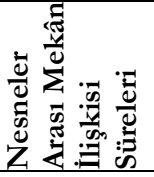 & $10-12$ & 42 & 68,50 & 73,87 & ${ }_{-0,024}$ & 0,981 & - \\
\hline
\end{tabular}

(-) isareti fark.ın anlamlı olmadĭ̆ın göstermektedir. $P>0.05$

Tablo 6. incelendiğinde, 10-12 yaşları arasındaki öğrencilerin şekil-zemin ilişkisi ve nesneler arası mekan ilişkisi becerilerine ilişkin aritmetik ortalamaların, 6-9 yaşları arasındaki öğrencilere göre daha yüksek olduğu, görsel eşleştirme ve görsel ayırt etme becerilerine ilişkin aritmetik ortalamalarının ise daha düşük olduğu gözlenmektedir. Bununla birlikte bu farklılığın anlamlı olup olmadığını belirlemek amacıyla yapılan bağımsız ttesti sonucuna göre, farklı yaşlardaki zihinsel engelli çocukların şekil-zemin ilişkisi, görsel eşleştirme, görsel ayırt etme ve nesneler arası mekân ilişkisi becerilerini gerçekleştirirken harcadıkları süreler arasında anlamlı bir fark bulunmamıştır ( $\mathrm{p}>0.05)$. Bu durum, yaş değişkeninin zihinsel engelli çocukların şekil-zemin ilişkisi, görsel eşleştirme, görsel ayırt etme ve nesneler arası mekân ilişkisi becerileri açısından görsel algılarını farklılaştırmadığı şeklinde yorumlanabilir

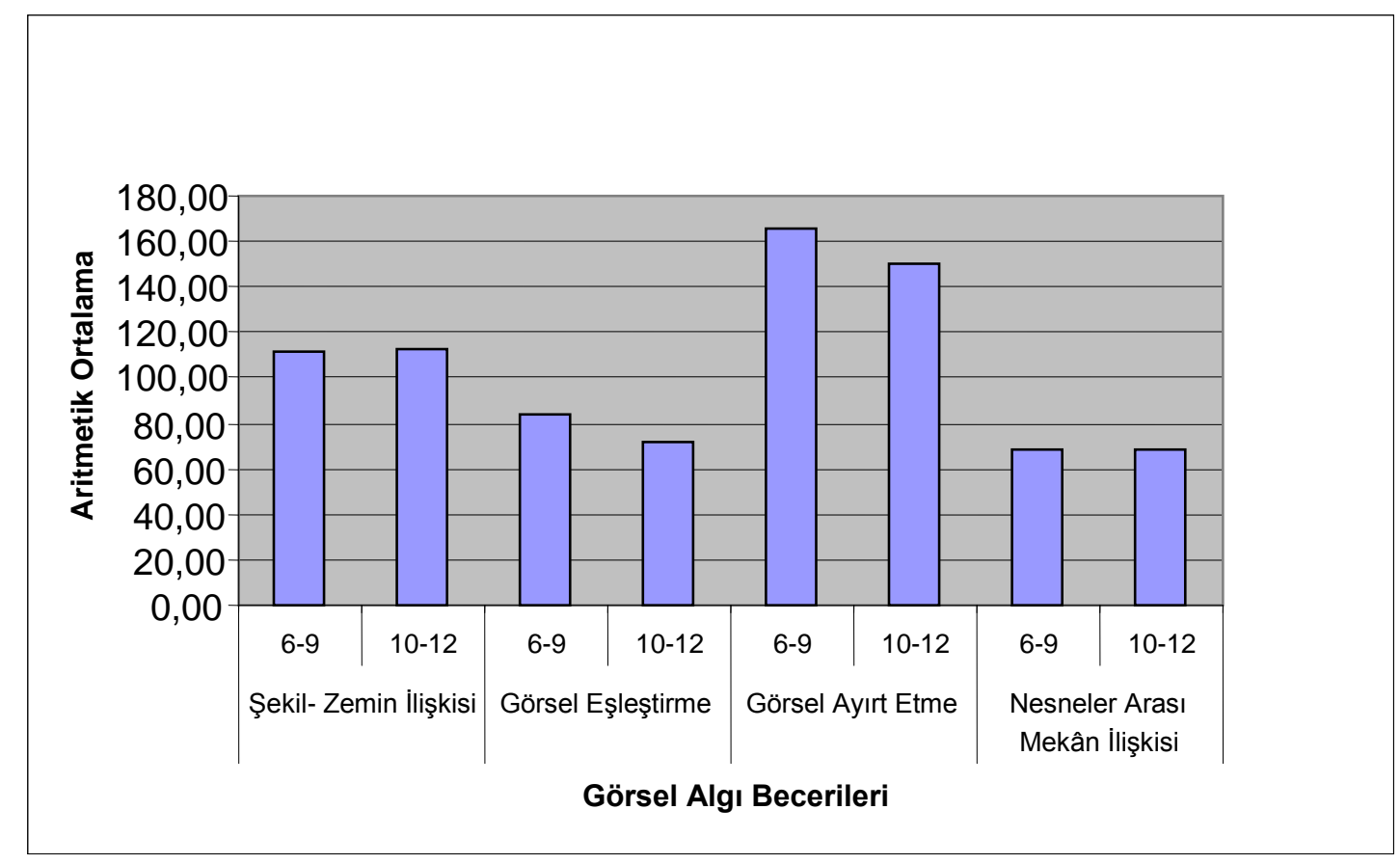

Şekil 5. Takvim Yaşlarına Göre Zihinsel Engelli Çocukların Görsel Alg1 Becerilerini Tanımada Araçları Tamamlama Sürelerinin Karşılaştırılması

\section{8. Özür Türlerine Göre Zihinsel Engelli Çocukların Görsel Algı Becerilerini Tanımada Araçları} Tamamlama Sürelerinin Karşılaştırılması

Araştırmanın altıncı alt probleminde özür türleri farklı olan zihinsel engelli çocukların görsel alg1 becerilerini tanıma durumları; şekil-zemin ilişkisi becerileri, görsel ayırt etme becerileri, görsel eşleştirme 
becerileri ile nesneler arası mekan ilişkisi becerileri alt boyutlarına yönelik olarak geliştirilen araç-gereç ve oyuncakları tamamlama süreleri açısından incelenmiş ve tablolaştırılarak, yorumlanmıştır.

Tablo 7. de özür türlerine göre öğrencilerin şekil-zemin ilişkisi becerileri, görsel ayırt etme becerileri, görsel eşleştirme becerileri ve nesneler arası mekan ilişkisi becerilerini gerçekleştirirken harcadıkları sürelerin karşılaştırılmasına ilişkin bağımsız t-testi sonuçları ile Şekil 4.2.3'de karşılaştırmalara ilişkin grafik verilmektedir. Mental retardasyon özür türü 1, diğer özür türleri (öğrenme güçlüğü, down sendromu, otizm, epilepsi vb.) ise 2 numaraları ile kategorilendirilmiştir.

Tablo 7. Özür Türlerine Göre Zihinsel Engelli Çocukların Şekil-Zemin İlişkisi, Görsel Eşleştirme, Görsel Ayırt Etme ve Nesneler Arası Mekân İlişkisini Tanımada Araçları Tamamlama Sürelerinin Karşılaştırılması

\begin{tabular}{|c|c|c|c|c|c|c|c|}
\hline & Özür Türü & $\mathrm{n}$ & $\bar{x}$ & ss & $t$ & $\mathrm{p}$ & Anlam \\
\hline \multirow{2}{*}{ 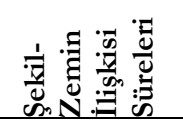 } & 1 & 56 & 112,82 & 67,75 & \multirow[t]{2}{*}{0,062} & \multirow[t]{2}{*}{0,95} & \multirow{2}{*}{-} \\
\hline & 2 & 29 & 111,86 & 66,26 & & & \\
\hline \multirow{2}{*}{ 兽: } & 1 & 32 & 82,34 & 32,32 & \multirow[b]{2}{*}{1,795} & \multirow[b]{2}{*}{0,079} & \multirow[b]{2}{*}{$*$} \\
\hline & 2 & 16 & 65,31 & 28,04 & & & \\
\hline \multirow{2}{*}{ 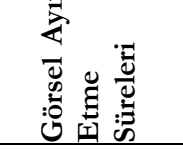 } & 1 & 47 & 154,51 & 44,47 & \multirow[b]{2}{*}{$\__{0,151}$} & \multirow[b]{2}{*}{0,881} & \multirow[b]{2}{*}{-} \\
\hline & 2 & 22 & 156,45 & 60,17 & & & \\
\hline \multirow{2}{*}{ 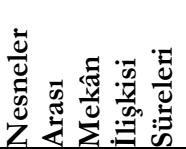 } & 1 & 43 & 68,65 & 70,53 & \multirow{2}{*}{ _0,025 } & \multirow{2}{*}{0,98} & \multirow[b]{2}{*}{-} \\
\hline & 2 & 19 & 69,11 & 48,68 & & & \\
\hline
\end{tabular}

(-) işareti fark.ın anlamlı olmadiğını göstermektedir. $P>0.05$

(*) işareti fark.n anlaml olduğunu göstermektedir. $P<0.05$

Tablo 7. . incelendiğinde, 1 numaralı özür türündeki öğrencilerin şekil-zemin ilişkisi, görsel eşleştirme becerilerine ilişkin aritmetik ortalamaların, 2 numaralı özür türündeki öğrencilere göre daha yüksek olduğu, görsel ayırt etme ve nesneler arası mekan ilişkisi becerilerine ilişkin aritmetik ortalamalarının ise daha düşük olduğu gözlenmektedir. Bununla birlikte bu farklılığın anlamlı olup olmadığını belirlemek amacıyla yapılan bağımsız t-testi sonucuna göre, görsel eşleştirme becerisi aşamasını tamamlama sürelerinde zihinsel engelli çocuklar arasında anlamlı bir fark bulunmuştur $(\mathrm{p}<0.05)$. Bu durum, özür türü değişkeninin zihinsel engelli çocukların görsel eşleştirme süreleri açısından görsel algılarını farklılaştırdığı şeklinde yorumlanabilir. Buna karşılık şekil-zemin ilişkisi, görsel ayırt etme ve nesneler arası mekan ilişkisi becerileri aşamalarını tamamlama süreleri incelendiğinde yapılan bağımsız t-testi sonucuna göre, farklı özür türlerindeki zihinsel engelli çocukların şekil-zemin ilişkisi, görsel ayırt etme ve nesneler arası mekan ilişkisi becerileri aşamalarını tamamlama süreleri arasında anlamlı bir fark bulunmamıştır ( $\mathrm{p}>0.05)$. Bu durum, özür türü değişkeninin zihinsel engelli çocukların şekil-zemin ilişkisi, görsel ayırt etme ve nesneler arası mekan ilişkisi becerileri aşamalarını tamamlama süreleri açısından görsel algılarını farklılaştırmadığı şeklinde yorumlanabilir. 


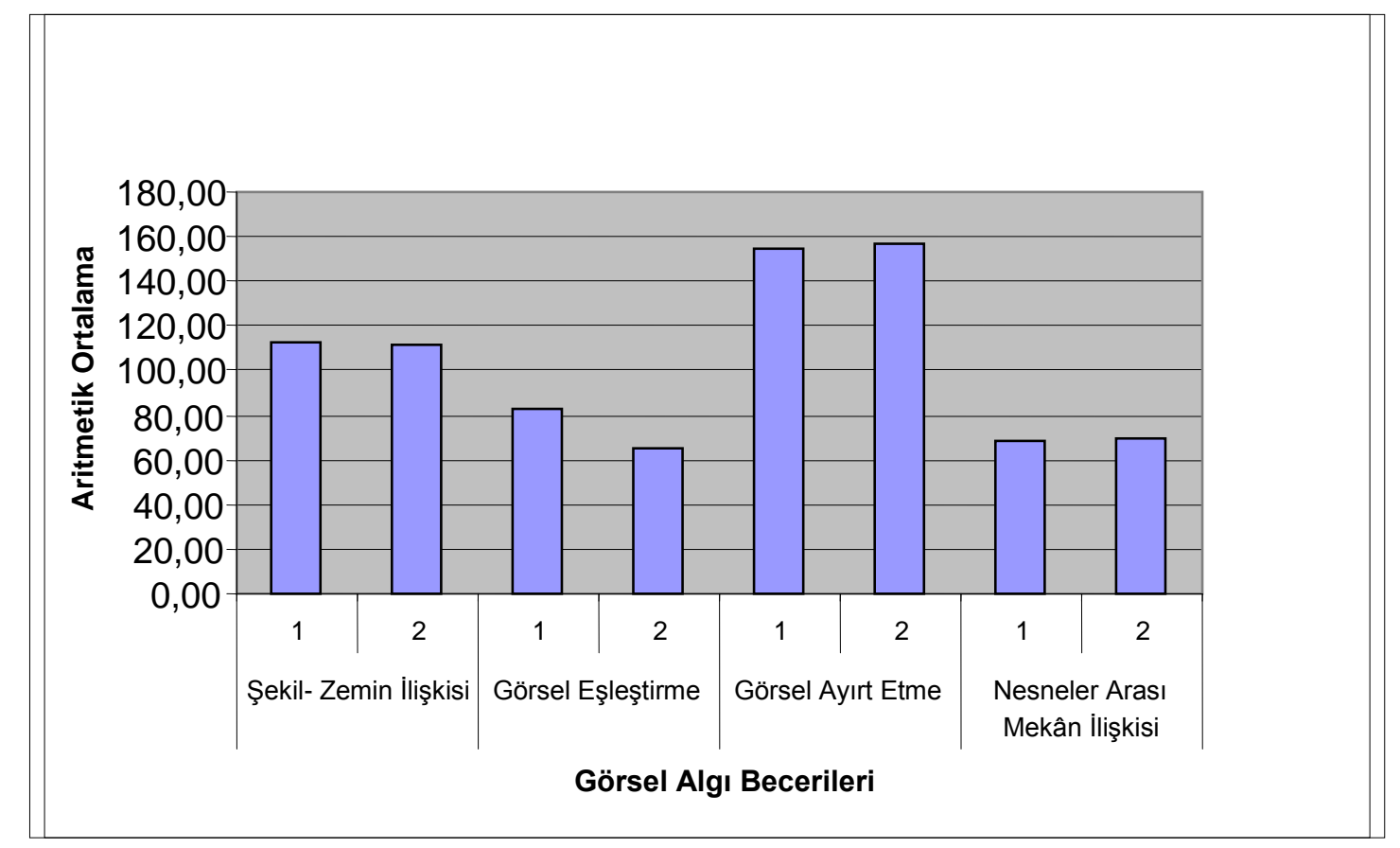

Şekil 6. Özür Türlerine Göre Zihinsel Engelli Çocukların Görsel Alg1 Becerilerini Tanımada Araçları Tamamlama Sürelerinin Karşılaştırılması

$\mathrm{Bu}$ çalışmada görsel algı becerilerine yönelik araç-gereç ve oyuncakların, oyuncakları tamamlama sürelerinin zihinsel engelli çocuklarda görsel alg1 becerilerinin gelişimine, yaş, cinsiyet ve özür türlerine göre etkililiği değerlendirilmiştir. Değerlendirme araştırmacı tarafından geliştirilmiş olan "Görsel Alg1 Becerilerini Değerlendirme Ölçü Aracı” ile yapılmıştır. Araç dört aşamadan oluşmaktadır. Birinci aşama şekil-zemin ilişkisi, ikinci aşama görsel eşleştirme, üçüncü aşama, görsel ayırt etme ve dördüncü aşama nesneler arası mekân ilişkileri olmak üzere görsel algının dört alt boyutunu içermektedir

\section{TARTIŞMA ve SONUÇ}

Bu bölümde zihinsel engelli öğrencilerin, yaşlarına, cinsiyetlerine ve özür türlerine göre şekil-zemin ilişkisi, görsel eşleştirme, görsel ayırt etme ve nesneler arası mekân ilişkisi becerileri ve aşamaları tamamlama süreleri arasında anlamlı bir fark olup olmadığı ile ilgili bulgulara yer verilmiştir.

4.1. Araştırmaya Katılan Zihinsel Engelli Öğrencilerin Cinsiyete Göre Görsel Alg1 Becerilerini

\section{Tanıma Durumlarının Değerlendirilmesi}

Araştırmaya katılan zihinsel engelli öğrencilerin cinsiyetlerine göre, şekil-zemin ilişkisi, görsel eşleştirme, görsel ayırt etme ve nesneler arası mekân ilişkileri becerileri incelendiğinde kız ve erkek öğrenciler arasında anlamlı bir farkın olmadığı görülmüştür. Elde edilen bu bulgu; Tuğrul ve diğerleri (2001) tarafından yapılan, altı yaşındaki çocukların görsel algılama düzeylerine frostig gelişimsel görsel algı eğitimi programının etkisinin incelenmesi adlı araştırma bulguları ile benzer özellik göstermektedir. Araştırmada Tüm alt alanlarda kız çocukları erkek çocuklarına kıyasla daha yüksek puan almış olmalarına rağmen, Göz motor koordinasyonu dışında diğer dört alt alandaki farklılık, istatistiksel olarak önemli bulunmamıştır. Göz-motor koordinasyonu alanında kız çocuklar erkek çocuklarına göre daha yüksek puan almıslardır.

Davis ve arkadaşları, okul öncesi çocuklarda görerek yapma sadece görme ve yalnızca söze dayalı olarak yapılan etkinliklerin sonradan ne kadar hatırlandığını araştırmışlardır. Göz- motor işbirliğine dayalı çalışmalarla daha kalıcı olduğunu görmüşlerdir. Anaokuluna giden ve gitmeyen çocuklara Frostig Görsel Alg1 Testi uygulanmış, anaokuluna giden çocukların görsel algılama alanlarında, anaokuluna gitmeyenlere göre daha başarılı olduklarını bulmuş ve görsel algılamada cinsiyetin önemli olmadığını tespit etmişlerdir (Sağol,1998; S:71-73). Daha önceden yapılan çalışmalarda çocukların yatay ve dikey görüşlerde cinsiyetin etkilerini araştırılmış ve kızlarla erkekler arasında önemli bir fark olmadığı sonucuna varılmıştır.Bu bulgular bizim çalışmamızı da destekler niteliktedir.

\subsection{Araştırmaya Katılan Zihinsel Engelli Öğrencilerin Takvim Yaşlarına Göre Görsel Alg1}

\section{Becerileri Tanıma Durumlarının Değerlendirilmesi}

Araştırmaya katılan zihinsel engelli öğrencilerin yaşlarına göre, şekil-zemin ilişkisi, görsel eşleştirme, görsel ayırt etme ve nesneler arası mekân ilişkileri becerileri incelendiğinde 6-12 yaş arası ve 9 yaş altı ile 10 yaş üstü olarak, yaşlarına göre kategorilendirilen öğrenciler arasında anlamlı bir farkın olmadığı görülmüştür. Bununla 
birlikte yapılan literatür incelemelerinde yaş değişkenine göre görsel alg1 çalışmalarının, genellikle normal çocuklar üzerinde ve Frostig Gelişimsel Görsel Alg1 Eğitim Programı ışığında gerçekleştirildiği görülmüştür.

Tuğrul ve Diğerleri (2001), altı yaşındaki çocukların görsel algılama becerilerini belirtmek ve algisal becerilerinin gelişimine Frostig Gelişimsel Görsel Alg1 Eğitim Programının etkisini tespit etmek amacıyla yaptıkları araştırmanın ilk aşamasında 127 çocuğa Frostig Gelişimsel Görsel Alg1 eğitimi Testi vermişlerdir. Bu çocuklar kesintisiz üç aylık dönemde haftada iki kez 45 dk’llk sürelerle Frostig Gelişimsel Görsel Alg1 eğitim Programına ait alıştırma kitaplarıyla çalışışlardır. Bu sürenin bitiminde çocuklara Frostig Gelişimsel Görsel Alg1 Eğitim Programı Testi son test olarak tekrarlanmıştır. Ancak bu aşamada çocuklardan bazıları araştırma kapsamı dışında kalınca son test ancak 110 çocukla tamamlanabilmiştir. Elde edilen bulgular Frostig Gelişimsel Görsel Alg1 Eğitim Programının çocukların görsel algilama becerilerinin tüm alt alanlarında "göz-motor koordinasyonu, şekil-zemin ayırımı, şekil sabitliği, mekanda konumun algılanması, makansal ilişkilerin algılanması" olumlu yönde bir destek sağladığını göstermiştir.

Deney grubundaki çocuklara Frostig Gelişimsel Görsel Alg1 Eğitim Programı ön testi ve Frostig Gelişimsel Görsel Alg1 Eğitim Programı son testi verilmiştir. Kontrol grubuna ise sadece Frostig Gelişimsel Görsel Alg1 Eğitim Programı ön testi ve son testi verilmiştir. Frostig Gelişimsel Görsel Algı Eğitim Programını alan ve almayan çocuklar arasında, eğitim programı alan çocukların lehine artışlar gözlenmiştir. Ancak, dört yaşındaki çocukların mekansal ilişkilerin algılanması ve mekanda konum alt alanlarında deney ve kontrol grubu farkları önemli bulunmamıştır. Diğer Tüm alanlarda Görsel algılama becerileri bakımından farklar, önemli bulunmuştur.

Beş altı yaşlarındaki çocukların Visio-motor yeteneğinin gelişiminde Frostig Gelişimsel Görsel Alg1 Eğitim Programının etkisini incelenmiştir. Anaokuluna devam eden çocuklardan deney ve kontrol grupları oluşturulmuş ve her iki gruba WPPSI geometrik design testi uygulanmıştır. Deney grubuna, Frostig Gelişimsel Görsel Alg1 Eğitim Programı verilmiştir. İki grup arasında fark olup olmadığına bakmak için Frostig Gelişimsel Görsel Alg1 Eğitim Programı tekrarlanmışve Frostig Gelişimsel Görsel Alg1 Eğitim Programı alan deney grubunda önemli bir farklılık gözlenmiştir.

Bizim araştırmamıza katılan çocukların zihinsel engelli oluşu ve zeka puanlarına bakılmamış olması gibi nedenlerden dolayı yaş ile görsel algı düzeyi arasında anlamlı bir ilişki bulunamamıştır.

4.2. Araştırmaya Katılan Zihinsel Engelli Öğrencilerin Özür Türlerine Göre Görsel Alg1 Becerileri Tanıma Durumlarının Değerlendirilmesi

Araştırmaya katılan zihinsel engelli öğrencilerin özür türlerine göre, şekil-zemin ilişkisi, görsel eşleştirme, görsel ayırt etme ve nesneler arası mekân ilişkileri becerileri incelendiğinde, görsel eşleştirme becerisi alt boyutu dışında, şekil- zemin ilişkisi, görsel ayırt etme ve nesneler arası mekân ilişkisi becerilerinde anlamlı bir fark bulunmuştur.

Araştırmaya, mental retardasyon, down sendromu, öğrenme güçlügü, epilepsi, otizm, gibi özür türlerine sahip öğrenciler katılmıştır. Araştırma sonrasında ise öğrencilerin sahip oldukları özür türleri 1 ve 2 numaraları verilerek kategorilendirilmiştir. Mental retardasyon özür türü 1, diğer özür türleri (öğrenme güçlüğü, down sendromu, otizm, epilepsi vb.) ise 2 numaraları ile kategorilendirilmiştir. Özür türü değişkenine göre görsel alg1 becerilerinin karşılaştırılmasında şekil- zemin ayrımı becerileri, görsel ayırt etme becerileri ve nesneler arası mekân ilişkisi becerilerinin $\mathrm{p}<0.05$ olduğundan farkın anlamlı olduğu, görsel eşleştirme becerilerinin karşılaştırılmasında ise $\mathrm{p}>0.05$ olduğundan anlamlı bir farkın olmadığı sonucuna varılmıştır.

Sağol (1998) Down sendromlu çocuklarla yaptığı çalışmasında Frostig Gelişimsel Görsel Alg1 Eğitim Programının çocukların görsel algı gelişimine etkisini araştırmıştır. Dokuz down sendromlu çocuk deney grubunda Frostig Gelişimsel Görsel Alg1 Eğitim Programını üç ay boyunca almış, dokuz down sendromlu çocuk ise kontrol grubunda her hangi bir eğitim almamıştır. Deney grubundaki çocukların Şekil Sabitliği, Şekil Zemin Ayrımı ve Göz motor Koordinasyonu alt alanlarında olumlu yönde gelişmeler tespit edilmiştir.

Epileptik çocukların görsel algı gelişimlerini ölçmek amacıyla yaptığı çalışmada, çocukların WISC testi ile Frostig testi sonuçlarının yakın ilişki içinde olduğunu saptamıştır (Sağol,1998; S:6). 
4.3. Araştırmaya Katılan Zihinsel Engelli Öğrencilerin Cinsiyete Göre Görsel Alg1 Becerilerini Tanımada Araçları Tamamlama Sürelerinin Değerlendirilmesi

Araştırmaya katılan zihinsel engelli öğrencilerin cinsiyetlerine göre, şekil-zemin ilişkisi, görsel eşleştirme, görsel ayırt etme ve nesneler arası mekân ilişkisi becerileri aşamaları tamamlama süreleri incelendiğinde kız ve erkek öğrenciler arasında anlamlı bir farkın olmadığı görülmüştür. Bununla birlikte yapılan literatür incelemelerinde cinsiyet değişkenine göre görsel alg1 çalışmalarının, görsel alg1 becerilerini tamamlama sürelerine göre yapıldığına ilişkin bulgulara rastlanmamıştır.

4.4. Araştırmaya Katılan Zihinsel Engelli Öğrencilerin Takvim Yaşlarına Göre Görsel Alg1 Becerilerini Tanımada Araçları Tamamlama Sürelerinin Değerlendirilmesi

Araştırmaya katılan zihinsel engelli öğrencilerin yaşlarına göre, şekil-zemin ilişkisi, görsel eşleştirme, görsel ayırt etme ve nesneler arası mekân ilişkisi becerileri aşamaları tamamlama süreleri incelendiğinde 6-12 yaş arası ve 9 yaş altı ile 10 yaş üstü olarak, yaşlarına göre kategorilendirilen öğrenciler arasında anlamlı bir farkın olmadığ1 görülmüştür. Bununla birlikte yapılan literatür incelemelerinde yaş değişkenine göre görsel alg1 çalışmalarının, görsel algı becerilerini tamamlama sürelerine göre yapıldığına ilişkin bulgulara rastlanmamışır.

\subsection{Araştırmaya Katılan Zihinsel Engelli Öğrencilerin Özür Türlerine Göre Görsel Alg1}

\section{Becerileri Tanımada Araçları Tamamlama Sürelerinin Değerlendirilmesi}

Araştırmaya katılan zihinsel engelli öğrencilerin özür türlerine göre, şekil-zemin ilişkisi, görsel eşleştirme, görsel ayırt etme ve nesneler arası mekân ilişkisi becerileri aşamaları tamamlama süreleri incelendiğinde, görsel eşleştirme becerisi alt boyutu dışında, şekil- zemin ilişkisi, görsel ayırt etme ve nesneler arası mekân ilişkisi becerilerinde anlamlı bir fark bulunmamıştır. Bununla birlikte yapılan literatür incelemelerinde özür türü değişkenine göre görsel algı çalışmalarının, görsel algı becerilerini tamamlama sürelerine göre yapıldığına ilişkin bulgulara rastlanmamıştır.

Araştırmaya, mental retardasyon, down sendromu, öğrenme güçlügü, epilepsi, otizm, gibi özür türlerine sahip öğrenciler katılmıştır. Araştırma sonrasında ise öğrencilerin sahip oldukları özür türleri 1 ve 2 numaraları verilerek kategorilendirilmiştir. Mental retardasyon özür türü 1, diğer özür türleri (öğrenme güçlüğü, down sendromu, otizm, epilepsi vb.) ise 2 numaraları ile kategorilendirilmiştir. Özür türü değişkenine göre görsel alg1 becerilerinin karşılaştırılmasında şekil- zemin ayrımı becerileri, görsel ayırt etme becerileri ve nesneler arası mekân ilişkisi becerilerinin $\mathrm{p}>0.05$ olduğundan anlamlı bir farkın olmadı̆̆ı, görsel eşleştirme becerilerinin karşılaştırılmasında ise $\mathrm{p}<0.05$ olduğundan farkın anlamlı olduğu sonucuna varılmıştır.

$\mathrm{Bu}$ araştırmada zihinsel engelli öğrencilerin görsel alg1 becerileri değerlendirilmiştir. Araştırma ilişkisel tarama modeline göre yapılmış olup yaş, cinsiyet ve özür türü değişkenlerinin görsel alg1 becerileri ve görsel alg1 becerilerini tamamlama sürelerine etkisi kıyaslanmıştır. Araştırmanın örneklemini Konya ilinde bulunan Milli Eğitim Bakanlığına bağlı özel ve resmi özel eğitim kurumları ve rehabilitasyon merkezlerine devam eden 6-12 yaş arası 41 kız ve 59 erkek olmak üzere 100 zihinsel engelli öğrenci oluşturmaktadır. Araştırmanın amaç bölümündeki verileri toplamak amacı ile araştırmacı tarafından informal "Görsel Alg1 Becerilerini Değerlendirme Ölçü Aracı” geliştirilmiştir. Araç, şekil zemin ilişkisi, görsel eşleştirme, görsel ayırt etme ve nesneler arası mekân ilişkisi olmak üzere görsel algın dört aşamasını içeren araç-gereç ve oyuncaklardan oluşmaktadır.

Araştırmanın sonunda zihin engelli öğrencilerin yaşları ile görsel alg1 becerileri tanıma durumları arasındaki ilişki incelendiğinde 9 yaş altı ve 10 yaş üstü olarak kategorilendirilen 6-12 yaş arası zihin engelli öğrencilerin yaşları ile şekil zemin ayrımı becerisi, görsel eşleştirme becerisi, görsel ayırt etme becerisi ve nesneler arası mekân ilişkisi becerisi üzerinde anlamlı bir farklılı̆̆ın olmadığı görülmüştür. Bunun nedeni; araştırmada sadece yaş değişkeninin değil aynı zamanda cinsiyet ve özür türü değişkenlerinin de dikkate alınmasından kaynaklanıyor olabilir.

Zihin engelli öğrencilerin cinsiyete göre görsel algı becerileri tanıma durumları arasındaki ilişki değerlendirilmiştir. Zihin engelli öğrencilerin cinsiyetleri ile şekil zemin ayrımı becerisi, görsel eşleştirme becerisi, görsel ayırt etme becerisi ve nesneler arası mekân ilişkisi becerisi üzerinde anlamlı bir farklıllğın olmadığ1 görülmüştür. Bunun nedeni; öğrencilerin görsel alg1 becerilerini genetik bir özellik olan cinsiyet 
değişkeninden daha çok bulundukları çevresel faktörler (ev ortamı, anne babanın sunduğu ilgi, eğitim imkânı vb.) etkiliyor olabilir.

Zihinsel engelli öğrencilerin özür türlerine göre görsel algı becerileri tanıma durumları arasındaki ilişki değerlendirilmiştir. Zihinsel engelli öğrencilerin özür türleri ile şekil zemin ayrımı becerisi, görsel ayırt etme becerisi ve nesneler arası mekân ilişkisi becerisi üzerinde $\mathrm{p}<0,05$ düzeyinde anlamlı bir farklılık olduğu görülmüştür. Bunun nedeni; öğrencilerin sahip oldukları özür türlerinin belirti, ağırlık derecesi ve niteliklerine göre farklılaşması ayrıca öğrenciler arasındaki bireysel farklılıklar olabilir. Özür türü ile görsel eşleştirme becerisi arasında ise $\mathrm{p}>0,05$ düzeyinde anlamlı bir farklılığın olmadığı görülmüştür. Bunun nedeni ise; bu beceriye yönelik olarak geliştirilen araçta bulunan şekillerden kare ile dikdörtgenin araştırmaya katılan zihin engelli öğrencilerin çoğunluğu tarafindan karıştırılması sonucu bu şekillerin eşleştirilmelerinin hatalı yapılmasından kaynaklanıyor olabilir.

Araştırmanın sonunda zihinsel engelli öğrencilerin yaşları ile görsel algı becerilerini tanımada araç-gereç ve oyuncakları tamamlama süreleri arasındaki ilişki incelendiğinde 9 yaş altı ve 10 yaş üstü olarak kategorilendirilen 6-12 yaş arası zihinsel engelli öğrencilerin yaşları ile şekil zemin ayrımı becerisi, görsel eşleştirme becerisi, görsel ayırt etme becerisi ve nesneler arası mekân ilişkisi becerisi aşamalarını, tamamlama süreleri üzerinde anlamlı bir farkl1lı̆ın olmadığ1 görülmüştür. Bunun nedeni; araştırmada sadece yaş değişkeninin değil aynı zamanda cinsiyet ve özür türü değişkenlerinin de dikkate alınmasından kaynaklanıyor olabilir.

Zihinsel engelli öğrencilerin cinsiyetlere göre görsel algı becerilerini tanımada araç-gereç ve oyuncakları tamamlama süreleri arasındaki ilişki değerlendirilmiştir. Zihinsel engelli öğrencilerin cinsiyetleri ile şekil zemin ayrımı becerisi, görsel eşleştirme becerisi, görsel ayırt etme becerisi ve nesneler arası mekân ilişkisi becerisi aşamalarını tamamlama süreleri üzerinde anlamlı bir farklıllğın olmadığı görülmüştür. Bunun nedeni; öğrencilerin görsel alg1 becerilerini tamamlama sürelerini genetik bir özellik olan cinsiyet değişkeninden daha çok bulundukları çevresel faktörler (ev ortamı, anne babanın sunduğu ilgi, eğitim imkânı vb.) etkiliyor olabilir.

Zihinsel engelli öğrencilerin özür türlerine göre görsel algı becerilerini tanımada araç-gereç ve oyuncakları tamamlama süreleri arasındaki ilişki değerlendirilmiştir. Zihinsel engelli öğrencilerin özür türleri ile şekil zemin ilişkisi becerisi, görsel ayırt etme becerisi ve nesneler arası mekân ilişkisi becerisi üzerinde $p>0,05$ düzeyinde anlamlı bir farklılığın olmadığ görülmüştür. Özür türü ile görsel eşleştirme becerisi arasında ise $\mathrm{p}<0,05$ düzeyinde anlamlı bir farklılık olduğu görülmüştür. Bunun nedeni; öğrencilerin sahip oldukları özür türlerinin belirti, ağırlık derecesi ve niteliklerine göre farklılaşması ayrıca öğrenciler arasındaki bireysel farklılıklar olabilir.

\section{5. Öneriler}

\subsection{Uygulamaya Yönelik Öneriler}

1. Zihinsel engelli bireylerin başarılı bir okuma öğreniminde, gerekli olan görsel alg1 eğitimine yönelik programların düzenlenmesi yararlı olabilir.

2. Görsel algının zihinsel engelli çocukların duygusal dengeleri üzerindeki önemli rolü ile ilgili olarak bu çocukların aileleri ve öğretmenlerinin konu ile ilgili olarak bilgilendirilmeleri yararlı olabilir.

3. Zihinsel engelli öğrencilerin özür türlerine göre ve özür türlerinin özelliklerine göre daha farklı araçgereç ve oyuncaklar geliştirilebilir.

\subsection{Yeni Araştırmalara Yönelik Öneriler}

1. Araştırmada görsel algı becerileri alt boyutlarından şekil zemin, görsel eşleştirme, görsel ayırt etme ve nesneler arası mekân ilişkisi becerileri değerlendirilmiştir. Yeni araştırmalarda görsel sınıflandırma ve görsel bellek alt boyutları da araştırılabilir.

2. Zihinsel engelli çocuklar ile normal çocukların görsel algı becerileri kıyaslanabilir.

3. Bu araştırmada zihinsel engelli çocukların görsel becerileri değerlendirilmiş ve eşleştirme aşamasında çoğunluk olarak kare ve dikdörtgeni birbirine karıştrdıkları görülmüştür. Yeni araştırmalarda kare ve dikdörtgen temel şekillerini öğretimine yönelik çalışmalar yapılabilir.

4. Bu araştırmada zihinsel engelli çocukların görsel algı becerileri değerlendirilmiştir. Yeni araştırmalarda diğer alg1 çeşitlerinin değerlendirilmesine yönelik çalışmalar yapılabilir. 
5. Bu araştırma ilişkisel tarama modeli ile yapılmıştır. Yeni araştırmalarda deney ve kontrol gruplu deneme modelleri kullanılabilir.

6. Bu araştırmada 100 zihinsel engelli öğrenci ile çalışlmıştır. Yeni araştırmalarda araştırmaya katılan denek sayısı daha az tutulabilir ya da 100 zihinsel engelli öğrenci içerisinden kesitler alınarak görsel alg1 becerileri incelenebilir veya zihinsel engelli bir grup öğrenci uzun yıllar boyu belli aralıklarla gözlenerek görsel becerileri değerlendirilebilir.

\section{KAYNAKÇA}

Açıkgöz, N.,Madi, B. (1998). Öğrenme ile Beyinde Oluşan Değişiklikler (Plastite). M.Ü Atatürk Eğitim Fakültesi Ë̆itim Bilimleri Dergisi 9. (29-36).

Akçamete, G. (1994). Bir Seminer Raporu. Özel Eğitim Dergisi, 1, 4 (55).

Akçin, N. (1993). Okuma Becerisinin Kazandırılmasında Görsel Alg1 Gelişiminin Rolü. Hacetepe Üniversitesi Sağhlk Bilimleri Enstitïsü. (12-13). Ankara.

Aral, N., Bulut, Ş.,Baran, G. ve Çimen, S. (2001). Çocuk Gelişimi. Ya-Pa yayıncılık. (S.85-128).Ankara.

Aşıcı, Murat. (2003). Çocuğum Okur Yazar Oluyor. Morpa Kültür Yayıncılık. (26-27).İstanbul.

Beykoç, D.,Çağlayan,N., Dinçer, A., Dereobalı, N., Gümüşçü, Ş., Pişkin, N. (2000). Okul Öncesi Dönemde Dil Gelişimi Etkinlikleri. Ankara Sim Matbaast (5 ). Ankara.

Büyükerşen, Y., Konrot, A., Topbaş, S., ve Baran, S. (1992). Zihin Engelliler İçin Alt Çalışma Gurubu Raporu. Eskişsehir Anadolu Universitesi Yaynnlar, Cilt 2 (1-7). Eskişehir.

Cavkaytar, A. (1999). Zihin Engellilere Özbakım ve Ev İçi Becerilerinin Öğretiminde Bir Aile Eğitimi Programının Etkinliği. Eskişehir Eğitim Fakültesi Yaymları (2). Eskişehir.

Cavkaytar, A., ve Diken,H,A. (2005) Özel Eğitime Giriş, Kök Yayıncllk. (30-33).Ankara.

Cirhinlioğlu, F,G,. (2001).Çocuk Ruh Sağlı̆̆ı ve Gelişimi. Nobel Yayın Dağıtım. (158-159).Ankara.

Kandır, A. (2003). Çocuğum Büyüyor. Morpa Kültür Yayıncılı..(46-47).İstanbul.

Whiteside, E., ve Simms, L.B.H. (1988). Zeka Özürlü Çocuklar-Zeka Özürlü Çocuklar İle Normal Çocukların Kaynaştırllmasıması. Karatepe Yayıncılı.. (3-6).Ankara.

Enç, M., Çağlar, D., ve Yahya Özsoy, Y. (1985). Özel Eğitime Giriş Ankara Üniversitesi Eŭitim Fakültesi Yayınları, (245-246).Ankara.

Eripek, S. (1996). Zihinsel Engelli Çocuklar Eskişehir Anadolu Üniversitesi Basımevi.(1-50).Eskişehir.

Eripek, S. (2005). Zeka Geriliği. Kök Yayıncllk (62-141). Ankara.

Gander, M,J., ve Gardiner, H.W. (1993). Çocuk ve Ergen Gelişimi , Çeviren :Bekir Onur,Imge Yayınevi. (247). Ankara.

Gönen, M., Dalkılıç N. V. (1999). Çocuk Eğitiminde Drama, Epsilon Yayınlar. (19).İstanbul.

Gürsel, O. (1993). "Zihinsel Engelli Çocukların, Doğal Sayıları, Gerçek Nesneleri Kullanarak Eşleme , Resimleri İşaret Ederek Gösterme, Rakamlar Gösterildiğinde Söyleme , Becerilerinin Gerçekleştirilmesinde , Bireyselleştirilmiş Öğretim Materyelinin Basamaklandırılmış Yöntemle Sunulmasının Etkililiği’”. Eskişehir Anadolu Üniversitesi Yayınlar .(21).Eskişehir.

Hilgard, E,R., Atkinson, R,L., (1995). Psikolojiye Giriş I. Sosyal Yayınlar. (192). İstanbul.

İbişoğlu, A. (1987). "4.0-9.0 Yaş Dilimindeki Epileptik ve Non Epileptik Çocukların Görsel Alg1 Gelişimi Açısından Karşılaştırılması”. İstanbul Üniversitesi, Çocuk Sağhğ̆ Enstitüsü, Gelişim Nörolojisi .İstanbul.

İnceoğlu, M. (2000). Tutum-Alg1 İletişim. İmaj Yayıncılk. (44-75).Ankara.

Luckasson, R. (1992)Mental Retardation: Definition, Classification and Systems of Support.American Association on Mental Retardation. (8-127).

MacMillan, D.L., Gresham, F.M., ve Sperstein, G.N. (1998). Conceptual and Psychometric Concerns Over the 1992 AAMR Definition of Mental Retardation. American Journal of Mental Retardation(325).

Öz, İ. (2007). Çocuk Olmak-Çocuğun Gelişim Dönemleri, Kök Yayıncılı.. (59).Ankara.

Sağol, U. (1998).Down Sendromlu Çocukların Görsel Algı Gelişimine Frostig Görsel Alg1 Eğitim Programının Etkisi. Yaynlanmamıs Yüksek Lisans Tezi, Marmara Üniversitesi. (51-73).İstanbul.

Sayın, Z. (1990).İ̧sitme Engelli Çocukların Eğitiminde Görsel Bildirişim Araçlarının Yeri ve Önemi. Ankara Üniversitesi Eğitim Bilimleri Fakültesi Eğitim Bilimleri I. Ulusal Kongre Bildirileri. (24-28).Ankara.

Sarı, H. (2002). Özel Eğitime Muhtaç Öğrencilerin Eğitimleriyle İlgili Öneriler. Pegem A Yayıncllk. (3). Ankara.

Senemoğlu, N. (2005).Gelişim, Öğrenme ve Öğretim Kuramdan Uygulamaya. Yorum Matbaası. (292294). Ankara.

Smith, M.B. (2002). Mental Retardation.Prentice-Hall, Inc.,(215).U.S. 
Tuğrul, B., Aral, N., Erkan, S., ve Etken, İ. (2001) Altı Yaşındaki Çocukların Görsel Algılama Düzeylerine Frostig Gelişimsel Görsel Alg1 Eğitim Programının Etkisinin İncelenmesi. Journal Of quafkaz Universty. $(2-10)$.

Varol, N. (1992). Zihinsl Engelli Çocuklara, Kırmızı, Sarı, Büyük ,Daire,Üçgen, Uzun, Bir Tane, İki Tane ve Kalın Kavramlarını Kazandırmada , Açık Anlatım Yöntemiyle Sunulan, Bireyselleşitirilmiş Kavram Öğretim Materyalinin Etkililiği. Anadolu Üniversitesi Yaynları. (10-15).Eskişehir.

Vatsa, R., Haith, M., ve Miller, S. (1992). “Child’s Psychology. John Wily and Sons Company. (199-201).USA

Voltan, A., Nilüfer, J., ve Whirter, J,M. (1984). Cocukla İletişim. (48).Ankara.

Özer, K. (2004). İletişim Becerisi, Varlk Yayınlar, (218-219).İstanbul

Özsoy, Y.,Özyürek, M., ve Eripek, Süleyman,. (2001) Özel Eğitime Muhtaç Çocuklar-Özel Eğitime Giriş, Karatepe Yaymlar .(240-250).Ankara.

Turan, A. (2004) Zihinsel Engellilerde Resim Eğitimi, Yaymlanmamıs Yüksek Lisans Tę̣i, Selçuk Üniversitesi. (5054).Konya.

Yıldız, Ü. (2000).“Deneysel Yaratıcılık Programının 4-5 Yaş Çocuklarının Sosyal ve Bilişsel Gelişimlerine Etkileri. Yayınlanmamıs Yüksek Lisans Teži,Selcuk Üniversitesi. (31-59).Konya.

Yörükoğlu, A. (2002). Çocuk Ruh Sağlığı.Özgür Yaymlar (118-119).İstanbul.

\section{Citation Information}

İnce, H. H., Akdemir, B, \& Yıldırm Doğru, S. S. (2017). 6-12 Yaş Arası Zihin Engelli Çocuklarda Görsel Alg1 Becerilerinin Değerlendirilmesi. Dicle Üniversitesi Ziya Gökalp Ë̆̈itim Fakültesi Dergisi, 31, 687-704. 